\title{
Comparison in Kambaata: Superiority, Equality and Similarity
}

\author{
Yvonne Treis \\ CNRS-LLACAN
}

This paper is an in-depth study of the expression of comparison in Kambaata, a Highland East Cushitic language of Ethiopia. It discusses not only quantitative comparison, i.e. comparison of relative and absolute inequality and comparison of equality, but also analyses the morphology and syntax of expressions of qualitative comparison, i.e. comparison of similarity. Apart from predicative constructions, the analysis takes into account attributive comparative, superlative, equative and similative constructions. In the comparative construction (lit. ' $X$ is tall from $Y$ '), the standard of comparison is marked by the ablative case, as in most languages spoken in the Horn of Africa. Kambaata distinguishes between two superlative constructions, one of which is based on the comparative construction ('X is tall from all'), while the other is characterised by a locative standard of comparison (' $X$ is tall among $Y$ '). Furthermore, Kambaata has two equative constructions. The first is based on the similative construction (' $X$ is tall like $Y$ '); the second is a periphrastic construction (' $X$ is tall to the extent $Y$ '). The paper argues that the enclitic morpheme which marks the standard of comparison in the similative construction originates from a noun meaning 'manner'.

\section{Introduction}

This paper is a study of the expression of comparison in Kambaata, a Highland East Cushitic language of Ethiopia. It encompasses analyses of quantitative and qualitative comparison. ${ }^{1}$ It is concerned with comparison of inequality ( $(3)$, similarity ( $(4)$ and equality $(\S 5)$. While works on comparison in little known languages often focus on predicative comparison constructions with simple nominal standards of comparison, I will go further, examining constructions with complex clausal standards and attributive comparison constructions. The first sections of this article provide information on the classification and location of the language (\$2) and give an overview of important grammatical aspects that are required as background for the discussion of comparison (§3-5). To the best of my knowledge, this paper is so far the most detailed study of the expression of comparison in a Cushitic language. My analyses are based on data collected during fieldtrips to the Kambaata-speaking area from 2002 to 2007 and in 2016. Apart from narratives, conversational data and mock dialogues, ${ }^{2}$ my corpus also includes texts from local publications. ${ }^{3}$ These sources are supplemented by elicited data. I have generally attempted to avoid translation elicitation but have resorted to target language manipulation elicitation or text-based (ancilliary) elicitation (Chelliah \& de Reuse 2011: 370-73, 379), whenever elicitation was necessary at all. All data is

\footnotetext{
${ }^{1}$ Financial support for this work came from the federation Typologie et universaux linguistiques: données et modèles (CNRS, FR 2559) via the project Expression des comparaisons d'égalité et de similitude (2014-2018). I am grateful to the Culture Department of the Kambaata-Xambaaro Zone for their support during my fieldtrips. Meaza Kerlos collected most of the written Kambaata sources. Mirja Saksa obtained the Kambaata translation of the Gospel of John for me. I am indebted to my language assistant, Deginet Wotango, for the intensive and fruitful discussions of the analyses proposed here. I would like to thank Teshome Dagne, Tessema Handiso and all the other Kambaata speakers I have been working with since 2002. Claudine Chamoreau, Kazuhiro Kawachi, Tatiana Nikitina, Martine Vanhove and Kasia Wojtylak gave valuable feedback on an earlier version of this paper.

${ }^{2}$ The sources of my corpus data are given in [square brackets].

${ }^{3}$ Local publications: K89 = Kambaatissata (1989), Geetaahun (2002), QL = Saint-Exupéry (2018), and John = Gospel of John (Kambaata and Hadiyya Translation Project Hosaina 2005).
} 
presented in the official Kambaata orthography (see Treis 2008: 73-80), supplemented by accents to indicate phonemically distinctive stress.

\section{Typological overview of Kambaata}

Within the Cushitic branch of the Afro-Asiatic language phylum, Kambaata belongs to the Highland East Cushitic (HEC) language group. It is spoken in the South of Ethiopia in an area approximately $300 \mathrm{~km}$ south-west of the Ethiopian capital Addis Ababa in the KambaataXambaaro Zone (Figure 1). The immediate neighbours of the Kambaata are speakers of other Highland East Cushitic languages (Alaaba and Hadiyya) and Ometo languages of the Omotic family (Wolaitta and Dawro). According to the 2007 Ethiopian census, there are 615,000 Kambaata speakers.

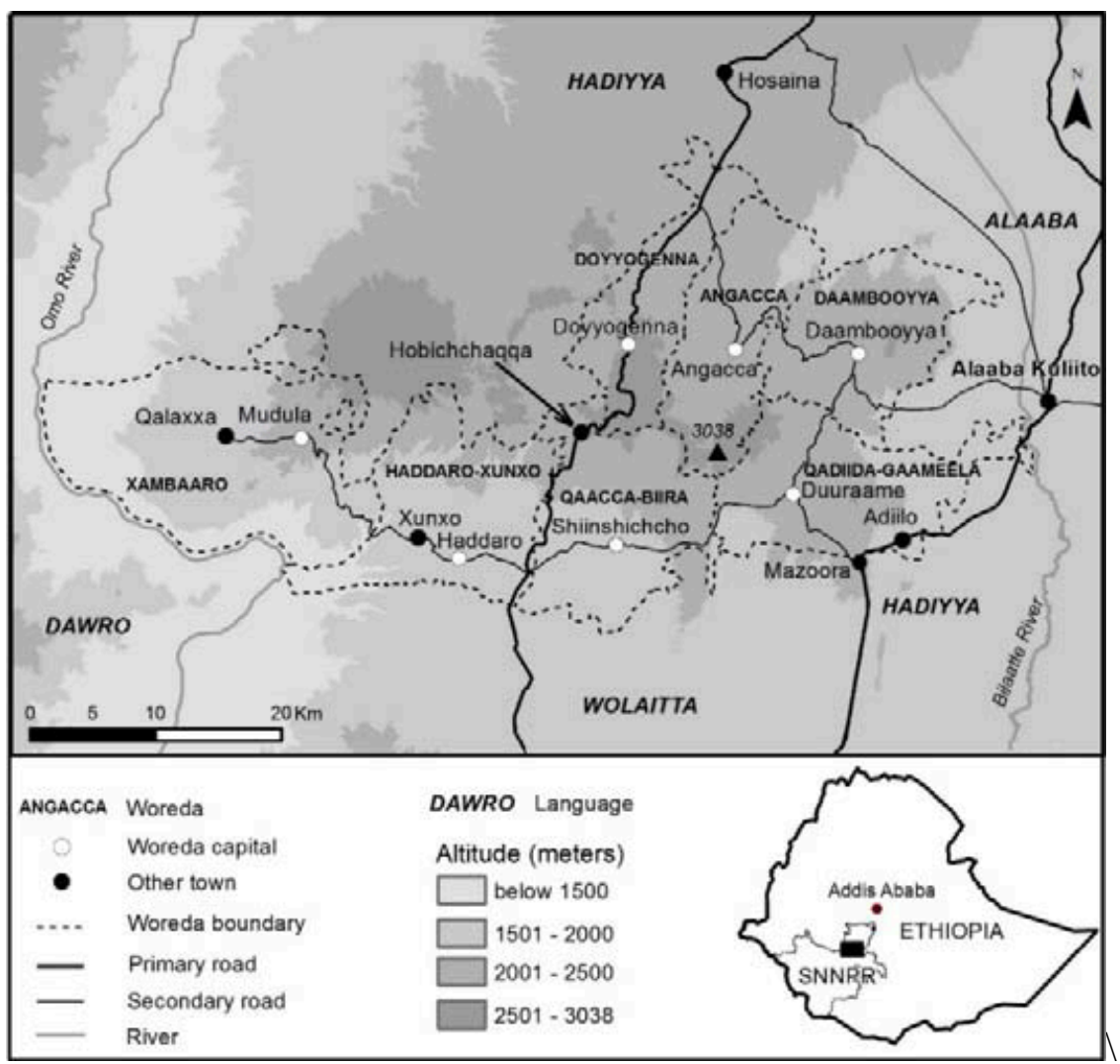

Figure 1. Kambaata-Xambaaro Zone and its woredas

(Map designed by Jérôme Picard, CNRS-LLACAN, 2016; Sources: ESRI, USGS data.humdata.org; all boundaries are unofficial)

Kambaata is exclusively suffixing and, regarding its morphological type, agglutinatinginflectional with many portmanteau morphemes. It is both head- and dependent-marking with a fairly elaborate case system and subject agreement on verbs. It is consistently head-final; hence all modifiers, including relative clauses, precede the noun in the noun phrase, and all dependent clauses precede independent main clauses. The main verb or a copula is usually the last constituent in the sentence. Clefting is a very common focussing device.

Kambaata has four major open word classes: nouns, adjectives, verbs and ideophones, all of which can be defined on the basis of morphological and morphosyntactic criteria (Treis 2008: 8197). Nouns are obligatorily specified for one of nine cases, and for either masculine or feminine 
gender. Table 1 exemplifies the case paradigms of the masculine noun $d u m-\dot{a}$ 'back room (of a house)' and the feminine noun gat-i-ta 'backyard'. The accusative is the functionally unmarked case. It marks not only direct objects but also certain temporal and manner adverbial phrases, and it serves as the citation form of nouns.

\begin{tabular}{|c|c|c|c|}
\hline & & $\begin{array}{l}\text { dum-á (m.) } \\
\text { 'back room' }\end{array}$ & $\begin{array}{l}\text { gat-i-ta (f.) } \\
\text { 'backyard' }\end{array}$ \\
\hline Accusative & ACC & dum-á & gat-i-ta \\
\hline Nominative & NOM & dúm-u & gát-i-t \\
\hline Genitive & GEN & dum-í & gat-é \\
\hline Dative & DAT & dum-ii(-ha) & gat-ée(-ha) \\
\hline Ablative & $\mathrm{ABL}$ & dum-ïichch & gat-éechch \\
\hline Instrumental/Comitative/Perlative & ICP & dum-íin & gat-éen \\
\hline Locative & LOC & dum-áan & gat-éen \\
\hline Oblique/Vocative & OBL & dúm-a & gát-e \\
\hline Predicative (with COP2) & PRED & dúm-a & gát- $i$ \\
\hline
\end{tabular}

In attributive function, adjectives agree in case and gender with their head noun. They are marked for three cases (nominative, accusative, oblique) and two genders (masculine, feminine). Apart from being used as modifiers, adjectives can be used as the head of a noun phrase without further measures (e.g. nominalisation, dummy head) being taken. In this syntactic function, they have the full case-marking potential, i.e. they inflect for nine cases.

Kambaata makes a morphological distinction between fully finite main clause verbs and various types of semi-finite and non-finite dependent clause verbs: relative verbs, converbs, purposive verbs and verbal nouns. In Table 2, the verbs are arranged from left to right on a scale of decreasing finiteness. While Kambaata has nine independent, case-inflecting personal pronouns (1s, 2s, 2hon, 3m, 3f, 3hon, 1p, 2p, 3p), subject agreement morphemes on verbs distinguish maximally between seven ( $1 \mathrm{~s}, 2 \mathrm{~s}, 2 \mathrm{hon}=2 \mathrm{p}, 3 \mathrm{~m}, 3 \mathrm{f}=3 \mathrm{p}$, 3hon, $1 \mathrm{p})$, and minimally between five forms $(1 \mathrm{~s}=3 \mathrm{~m}, 2 \mathrm{~s}=3 \mathrm{f}=3 \mathrm{p}, 2$ hon $=2 \mathrm{p}$, 3hon, $1 \mathrm{p})$.

\begin{tabular}{|l|c|c|c|c|c|}
\cline { 2 - 6 } \multicolumn{1}{c|}{} & $\leftarrow$ FULLY FINITE & \multicolumn{4}{c|}{ NON-FINITE $\rightarrow$} \\
\cline { 2 - 6 } \multicolumn{1}{c|}{} & MAIN VERBS & $\begin{array}{c}\text { RELATIVE } \\
\text { VERBS }\end{array}$ & CONVERBS & PURPOSIVES & $\begin{array}{c}\text { VERBAL } \\
\text { NOUNS }\end{array}$ \\
\hline $\begin{array}{l}\text { SUBJECT } \\
\text { AGREEMENT }\end{array}$ & $5-7$ forms & $5-7$ forms & 5 forms & 5 forms & - \\
\hline ASPECT & $\begin{array}{c}\text { Imperfective } \\
\text { Progressive } \\
\text { Perfective } \\
\text { Perfect }\end{array}$ & $\begin{array}{c}\text { Imperfective } \\
\text { Progressive } \\
\text { Perfective } \\
\text { Perfect }\end{array}$ & $\begin{array}{c}\text { Imperfective } \\
\text { Perfective }\end{array}$ & - & - \\
\hline MOOD & $\begin{array}{c}\text { Indicative } \\
\text { Imperative/Jussive } \\
\text { Apprehensive }\end{array}$ & - & - & - & - \\
\hline NEGATION & + & - & + & - & - \\
\hline $\begin{array}{l}\text { SWITCH } \\
\text { REFERENCE }\end{array}$ & - & - & + & & - \\
\hline
\end{tabular}

Table 2. Inflectional categories on main and dependent verbs in Kambaata $(+/-=$ category can or cannot be morphologically marked) 
Ideophones are invariable and are always accompanied by a support verb which carries the inflection. In intransitive clauses ideophones combine with $y$ - 'say' or ih- 'become', and in transitive clauses with $a$ '- $\sim$ ass- 'do'.

\section{Comparison of inequality}

Comparison of inequality subsumes comparison of superiority and inferiority. For both types of comparison, a distinction can be made between relative inequality (e.g. Susan is taller than Peter; Peter is less tall than Susan) and absolute inequality (superlativity) (e.g. Susan is the tallest of her family; Peter is the least tall of his family). Kambaata does not have a grammaticalised construction for comparison of inferiority, but expresses inferiority periphrastically (§3.3). Hence the focus of this section will be on comparison of superiority $(\S \S 3.1-3.2)$.

\subsection{Comparison of superiority}

In the Kambaata predicative comparative construction, the comparee functions as the subject. As such, it is nominative-marked, e.g. Bóq, the nominative form of the personal name Boqé in (1). The parameter of comparison is expressed by the predicate, which is a member either of the word class of adjectives (1), or of the sub-word classes of property ideophones (2) or property verbs (4). ${ }^{4}$ The comparee in subject function triggers gender agreement on adjectival parameters and person/gender agreement on verbal parameters and on support verbs of ideophonic parameters (agreement is marked by underlining in (1)-(2)).
(1) Bóq
\{Makkeeb-éechch\} qeráa'rr-u-a

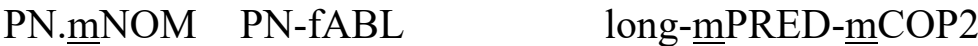

'Boqe is taller than Makkeebe (lit. Boqe is tall \{from Makkeebe\}).' (K89: 2.79)

(2)

$\begin{aligned} & \text { Buttu'll-a-sí hagár-u } \\ & \text { cubs-fGEN-DEF colour-mNOM }\end{aligned}$
gambáll $\quad y$-áano
adult-PL1-fGEN-DEF=NMZ2-mABL
'The colour of the (civet) cubs is darker than that of the adults (lit. The colour of the
cubs is dark ffrom that of the adults\}).' (K89: 6.56)

There is no grammaticalised parameter marker; the form of the parameter itself is no different from that of the positive construction (see the literal translation). The standard of comparison, i.e. the entity against which the comparee is measured and found to be unequal, is expressed by an ablative-marked adjunct. In (1) and all following examples, the standard phrases occur in curly brackets in the Kambaata and the translation line. The primary elements of the predicative comparative construction and their grammatical functions are summarised in (3).

\footnotetext{
${ }^{4}$ The terms "property ideophone" and "property verb" include those members of the word classes of ideophones and verbs that are cognate with (i.e. have the same stem as) an adjective, e.g. gambáll $y$ - (ideophone) 'be(come) black' gamball-á(-ta) (adjective) 'black'; qeraa'rr- (verb) 'be(come) tall, long' - qeraa'rr-ú(-ta) 'tall, long'.
} 
(3) Predicative comparative construction

(i) Adjectival parameter

$\begin{array}{lll}\text { Comparee } & \text { Standard } & \text { Parameter } \\ \text { GENDER }_{\mathrm{i}} / \text { NOM } & \text { GENDER }_{\mathrm{j}} / \mathrm{ABL} & \text { GENDER }_{\mathrm{i}} / \mathrm{COP} \\ \text { SUBJECT } & \text { ADJUNCT TO PARAMETER } & \text { PREDICATE }\end{array}$

(ii) Verbal parameter

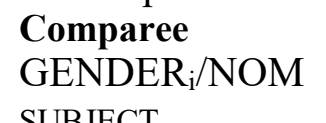

Standard

Parameter

SUBJECT

GENDER $_{\mathrm{j}} / \mathrm{ABL}$

ADJUNCT TO PARAMETER

GENDER $_{\mathrm{i}} /$ PERSON $_{\mathrm{i}} / \mathrm{TAM}$

PREDICATE

Whereas two entities are compared in (1)-(2), one can also compare two conditions of one and the same entity at different times. In (4), a current medical condition is compared to the previous condition, and a temporal noun serves as the standard of comparison.

$$
\begin{aligned}
& \text { (...) íib-u-si-i muggítt-uhu-u \{won-áachch\} } \\
& \text { fever-m.NOM-3mPOSS-ADD diarrhea-mNOM-ADD before-fABL } \\
& \text { woyy-án marr-óochch (...) } \\
& \text { be_better-3mIPV go-3mPFV.REL.ABL } \\
& \text { ' }(\ldots) \text { if the fever and the diarrhoea get better } \text { than before }\},(\ldots) . \text { ' (K89: 4.8) }
\end{aligned}
$$

The occurrence of the ablative case is not restricted to the comparative construction. Elsewhere in the language, the ablative case marks oblique objects and adjuncts which may express the source (5), origin or starting point of an actual (literal) or metaphorical (figurative) movement, the starting point in time, the source material of a production process, what is avoided, what one is protected or saved from (6), or the maleficiary of an event.

$\begin{array}{lll}\text { Daalal-óochch } & \text { buul-á } & \text { argicc-áamm } \\ \text { PN-mABL } & \text { mule-mACC } & \text { borrow.MID-1sIPV } \\ \text { 'I borrow a mule from Dalaalo.' (K89: 1.88) }\end{array}$

$$
\begin{aligned}
& \text { (...) gid-iichchí-i wól-o daaf-iichchí-i } \\
& \text { cold-mABL-ADD other-mOBL danger-mABL-ADD }
\end{aligned}
$$

ka'mm-am-áan-sa

protect.MID-PASS-1sIPV-3pO

'I protect them from cold and other dangers.' (K89: 3.47)

Furthermore, some relational nouns, such as zakk-ú 'after', etar-ú 'beyond, exterior; apart (from)' and bir-ita 'before, front', and some adjectives, such as annann-á(-ta) 'different (from)' and wol$u$ '-ita 'other (than)' (7), govern ablative complements.
Góoll-u
maal-1íchch
wol-ú $=r r-a$
it-táa-ba'a
civet_cat-fNOM
meat-mABL other-mACC $=\mathrm{NMZp-mACC}$
eat-3fIPV-NEG1
'The civet cat doesn't eat anything other than meat.' (K89: 6.57) 
The Kambaata canonical comparative construction would be categorised into the common comparative typologies as follows: In Stassen's typology, it would be labelled a Separative Comparative (1985: 39f), because the standard of comparison is encoded as an adverbial phrase with a separative ('from') interpretation. Like most languages employing this comparative construction type (Stassen 1985: 40), Kambaata has SOV constituent order. In Stassen's less-fine grained WALS typology (2013), the Kambaata comparative construction would be labelled a Locational Comparative, the most common worldwide type. In Dixon's (2008) typology, the Kambaata comparative construction would be labelled type A1, which subsumes constructions in which the parameter is the head of a copula complement or a verbless clause complement and in which the comparee is encoded as the subject and the standard of comparison as an oblique NP (2008: 789f). In Heine's (1997: 112) typology, the Kambaata comparative construction follows the Source schema (' $\mathrm{X}$ is Y from Z'). Zelealem \& Heine (2003: 56f) claim that the Source Schema is the primary schema of the Ethiopian Linguistic Area but uncommon elsewhere in sub-Saharan Africa. Thus Kambaata is a typical Ethiopian language with respect to the encoding of comparison of superiority.

\subsubsection{Constituent order}

As seen in (1)-(2) above, the basic constituent order in the comparative construction is

\section{Comparee - Standard - Parameter}

As is expected of a rigidly head-final language, the parameter is always the final constituent of the comparative construction. The order of comparee and standard is, however, pragmatically determined to a certain extent, and examples in which the comparee follows the standard are also attested in my corpus. Interrogative comparative examples are a case in point: in (8), a speech act participant is asked to which entity the parameter of comparison (richness) is applied to a higher degree. By the very nature of being questioned, it is undetermined which one of the two compared entities serves as the comparee or standard. Hence both entities are encoded in coordinated, additive-marked ablative NPs. The subject function is occupied by a question pronoun enquiring about the comparee. The question pronoun is placed in the pre-predicate slot, as is typical of nonclefted interrogative sentences in Kambaata.

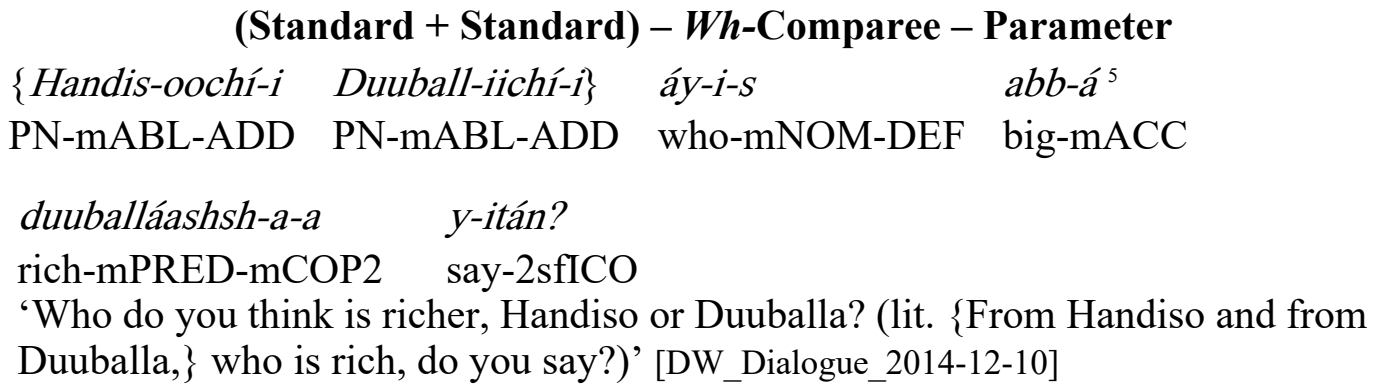

If the sentence focus is on the comparee it occurs in the pre-predicate slot. ${ }^{6}$

\footnotetext{
${ }^{5}$ According to a native speaker, $a b b-\dot{a}$ 'big; much' is not obligatory in (8). It implies here that both men are rich, while this implication is absent without $a b b-a$ (in this case one of the two would be expected to be poor).

${ }^{6}$ As suggested by an anonymous reviewer, one could also assume that the standard is topicalised in (9). The pragmatic factors determining the constituent order remain to be explored.
} 


\begin{tabular}{|c|c|c|}
\hline $\begin{array}{l}\{\text { Ba'-is-soontí } \\
\text { turn_bad-CAUS-2sPFV.REL }\end{array}$ & $\begin{array}{l}\text { ba'-is-íichch\} } \\
\text { turn_bad-CAUS-mABL }\end{array}$ & $\begin{array}{l}\text { qophphán-u-kk } \\
\text { lie-mNOM-2sPOSS }\end{array}$ \\
\hline $\begin{array}{l}\text { baas-á } \\
\text { much more-mACC }\end{array}$ & bad-mPRED-mCOP2 & \\
\hline
\end{tabular}

' $\{$ Compared to (lit. from) the mischief you have done\} your lie is much/even worse.' (K89: 4.45)

$\begin{array}{llll}\{\text { Ben-á } & \text { ir-1́ichch }\} & \text { Aacaam-é } & \text { ír-u-bay } \\ \text { PN-fGEN } & \text { land-mABL } & \text { PN-fGEN } & \text { land-mNOM-RHET }\end{array}$

lét-a-a-nii?

green-mPRED-mCOP-ADD

'\{Compared to (lit. from) Bena's land, $\}$ isn't Aacaame's land greener?' [Elicited]

The canonical constituent order Comparee - Standard - Parameter is not retained in the attributive comparative construction (see §3.1.4).

\subsubsection{Higher and lower degree of superiority}

The comparative construction can be expanded by adverbial modifiers specifying the degree of superiority. The converb form of abbis- 'exceed' (11), ${ }^{7}$ multiplicative numerals (12) or ACCmarked adjectives in adverbial function, e.g. qah-ú 'small, a bit' (13) and baas-á 'much more' (9), occur before the parameter.

\begin{tabular}{lllll} 
Mannoom-á & íib-u & \{bikk-íichchi-s $\}$ & \multicolumn{2}{l}{ abbíshsh } \\
body-fGEN & heat-mNOM & norm-mABL-DEF & exceed.3mPCO \\
abb-ée $=d a$ & & $(. .)$. & móos-i-ta & mal-áa \\
be_big-3mPFV.REL=COND & & illness-mGEN-fCOP2 & sign-fPRED
\end{tabular}

'If the body temperature is much higher (lit. exceedingly high) (...) \{than its norm $\}$, it is a sign of an illness.' (K89: 8.101)

$\begin{array}{llll}\text { Ziishsh-í } & \text { wom-á } & \text { umúr-u } & \{\text { wól-ua-n-s } \\ \text { bee-mGEN } & \text { queen-fGEN } & \text { age-mNOM } & \text { other-m.OBL-N-DEF }\end{array}$

ziishsh-í=hann-íichch $\} \quad$ ont-íta $\quad$ kod-áta $\quad$ qeraa'rr-áno bee-mGEN=NMZ2-mABL five-fACC time-fACC be long-3mIPV 'The queen bee lives five times longer than the other bees (lit. The age of the queen bee is five times long \{from that of the other bees\}).' (K89: 4.27)

\footnotetext{
${ }^{7}$ The verb abbis- 'exceed' is the causative form of $a b b$ - 'be(come) big, great, honoured'.
} 
(13)
$M e^{\prime}$-áa
waaliy-íchch-ut
\{goon-ch-íichchi-S\}
$q a h-u ́ l<n>k a$
female-fGEN
walia-SG-fNOM
male-SG-mABL-DEF
small-fACC $<\mathrm{N}>$
gabbéem-a-ta

short-fPRED-fCOP2

'The female walia ibex is a bit shorter $\{$ than the male (walia ibex) $\}$.' (K89: 5.40)

The adjective $a b b-a ́(-t a)$ 'big; much' fulfils various functions in the comparative construction. Firstly, it can express the parameter of comparison as in (14).

$\begin{array}{lll}\text { Baad-óon-ta-nne } & \{\text { shomboq-íin } & \text { hujat-eennó } \\ \text { country-mLOC-L-1sPOSS } & \text { bamboo_species-mICP } & \text { work-3honIPV.REL }\end{array}$

huj-éechch\} leem-íin hujat-eennó húj-it

work-fABL bamboo_species-mICP work-3honIPV.REL work-fNOM

$a ́ b b-a-t a$

big-fPRED-fCOP2

'In our country, work with shomboqu-bamboo is more widespread (lit. big, much)

\{than work with leema-bamboo\}.' (K89: 6.53)

Secondly, if modifying the parameter, it marks a higher degree of superiority of the comparee with respect to the standard (15), and thus has the same function as the degree adverbials in (11)-(13).

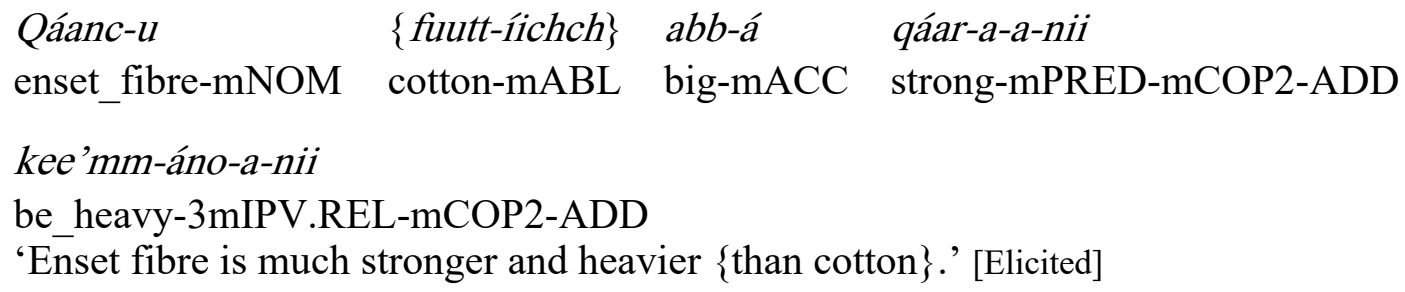

If fully reduplicated, $a b b-\dot{a}$ 'big; much' can express an extra-high degree of superiority (16).

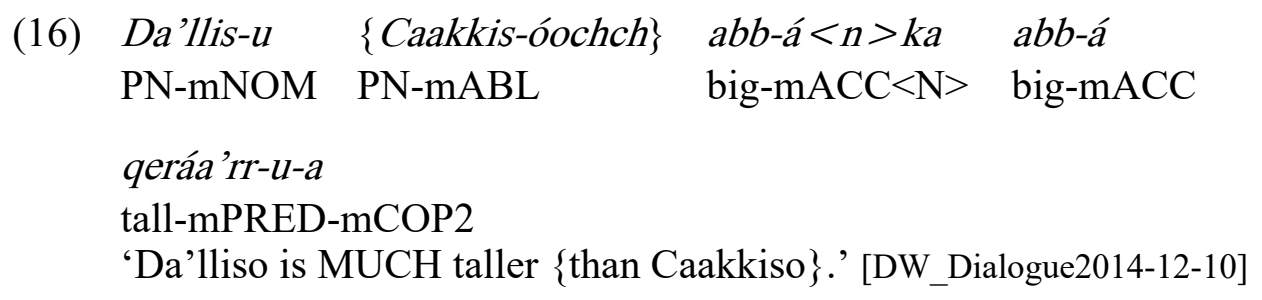

Thirdly, abb-á 'big; much' makes comparison of superiority possible, if the predicate of the clause is not an adjective, property verb or property ideophone; see the non-property verb qorab- 'take care' in (17). 

Hadar-áta \{beet-1ichch\}
$a b b-a ́$
qoráb-u
deposit-fACC son-mABL
big-mACC take_care-mNOM

has-is-áno

want-CAUS-3mIPV

'One has to take more/better care of the thing/person left in one's safekeeping \{than of one's son\}.' (K89: 5.48)

For the use of $a b b-\dot{a}$ 'big; much' with clausal standards see $\S 3.1 .3$.

Kambaata has two inherently comparative adjectives, woyy-á(-ta) 'better' (24) and baas-á(-ta) 'worse, (negative) more' (19), ${ }^{8}$ and two corresponding inchoative-stative verbs woyy- 'be(come) better' (18) and baas- 'be(come) worse, (negative) more'. ${ }^{9}$ Even if no standard of comparison is mentioned in the immediate context, these property lexemes imply that two (or more) entities are compared to each other and that the comparee exhibits the parameter encoded by the adjective to a higher (or, depending on the context, to the highest) degree.

Xuujj-oommí $=g$-iin át $\quad$ esáachch $\}$ abbís-s woyy-íteent see-1sPFV.REL=G-mICP 2sNOM 1sABL exceed-2sPCO be better-2sPRF 'I can see (that) you are/have become much better than me.' (K89: 3.4)

\section{Tíin \\ báas-a-ta \\ buxím-a}

P DEM1.fNOM worse-fOBL-fCOP2 poverty-fPRED

'This is worse/the worst poverty.' (Possible context: Last year, we were extremely poor, but this year the situation is even worse.) [Elicited]

\subsubsection{Clausal standards}

If a whole clause headed by a finite verb expresses the standard, it is nominalised (NMZ2) so that it can carry a case morpheme (20)-(21). Clausal standards are commonly followed by the degree marker abb-á 'big, much' (20) or aluud-ú (ACC) (20) / alúud-iin (ICP) 'above' (21). ${ }^{10}$

$$
\begin{aligned}
& \text { Xáph-u-s } \quad \text { has-is-anó=hann-íichch }\} \\
& \text { root-mNOM-DEF want-CAUS-3mIPV.REL=NMZ2-mABL } \\
& \text { aluud-ú (or: } a b b-\hat{a}) \quad \text { qeraa'rr-ée }=d a(\ldots) \\
& \text { above-mACC }[\sim \text { big-mACC }] \text { become_long-3mPFV.REL=COND } \\
& \text { 'If the roots grow longer }\{\text { than desired (lit. it makes want)\}, (...).' (K89: 8.9) }
\end{aligned}
$$

\footnotetext{
${ }^{8}$ Baas-á can also be used as an intensifier in adverbial function (9).

${ }^{9}$ Inherently comparative lexemes meaning '(be/become) better', some of which are cognate to the Kambaata lexeme, can be found in related East Cushitic languages, e.g. K'abeena/Alaaba $k$ 'oh- 'be better' (Crass 2005: 296, SchneiderBlum 2007: 95), Sidaama/Gedeo woyya 'better' (Kawachi 2007: 38, Wedekind 1990: 405), Konso woyy- 'be better' (Ongaye 2013: 167), Oromo wayya 'be better' (Gragg 1982: 402).

${ }^{10}$ Aluud-ú 'above; north' and alúud-iin 'above' are used outside the context of comparison as locative adverbials; they have resulted in the merger of al-í wud-ú (up-mGEN side-mACC) and al-í wud-íin (up-mGEN side-mICP).
} 


$\begin{array}{lll}\text { Gajáajj-u-S } & \{\text { has-is-anó=hann-íichch }\} & \begin{array}{l}\text { alúud-iin } \\ \text { reason-fNOM-DEF }\end{array} \\ \text { want-CAUS-3mIPV.REL=NMZ2-mABL } & \text { above-mICP }\end{array}$

hígg ${ }^{11} \quad$ shamm-ó= tannéehaa-t

pass.3fPCO rot-3mPFV.REL=REAS.VV-COP3

'The reason (for these bananas tasting bad) is that they are riper (lit. more rotten) \{than desired (lit. it makes want) \}.' [TH_Tä2003-09-05]

If the clause is headed by a verbal noun, which retains the argument structure of a verb but inflects like a noun (Treis 2012), no additional nominalisation is necessary. In (22), verbal nouns are used as heads of the standard and the comparee NP.

\{Beeh-1íchch\} méxxin ít-u wóyy-a-a
share-mABL alone eat-mNOM better-mPRED-mCOP2
'Eating alone is better $\{$ than sharing\}.' [Elicited]

\subsubsection{Attributive comparative construction}

Apart from the predicative comparative construction, Kambaata also has an attributive comparative construction (23). Here all components of the comparative construction are found inside one NP. The comparee is the head of the NP, which can occupy any syntactic function in the clause. It is modified by a phrase containing the parameter preceded by the ablative-marked standard. Adjectival parameters agree with the comparee in case and gender (23-i); verbal parameters ${ }^{12}$ show gender and person agreement and need to be relativised (23-ii). If the relative verb expressing the parameter is negative, it also agrees in case (and, again, in gender) with the head; ${ }^{13}$ this additional agreement morpheme occurs in round brackets in (23-ii).

(23) Attributive comparative construction

(i) Adjectival parameter - see ex. (24)

\begin{tabular}{|c|c|c|}
\hline$[[\{$ Standard $\}$ & Parameter] & Comparee $]_{\mathrm{NP}}$ \\
\hline GENDER $_{\mathrm{j}} / \mathrm{ABL}$ & $\mathrm{CASE}_{\mathrm{i}} / \mathrm{GENDER}_{\mathrm{i}}$ & $\mathrm{CASE}_{\mathrm{i}} / \mathrm{GENDER}_{\mathrm{i}}$ \\
\hline ADJUNCT TO & ATTRIBUTE TO & ANY SYNTACTIC \\
\hline PARAMETER & COMPAREE & FUNCTION \\
\hline \multicolumn{3}{|c|}{ Verbal parameter - see ex. (25) } \\
\hline$[[\{$ Standard $\}$ & Parameter $]_{\text {MODIFIER }}$ & Comparee $]_{N P}$ \\
\hline GENDER $_{\mathrm{j}} / \mathrm{ABL}$ & $\begin{array}{l}\text { GENDER }_{\mathrm{i}} / \text { PERSON }_{\mathrm{i}} / \mathrm{TAM} / \mathrm{REL} \\
\left(-\mathrm{CASE}_{\mathrm{i}} / \mathrm{GENDER}_{\mathrm{i}}\right)\end{array}$ & $\mathrm{CASE}_{\mathrm{i}} / \mathrm{GENDER}_{\mathrm{i}}$ \\
\hline ADJUNCT TO & ATTRIBUTE TO & ANY SYNTACTIC \\
\hline PARAMETER & COMPAREE & FUNCTION \\
\hline
\end{tabular}

The attributive comparative construction is exemplified in (24)-(26). In (24), two coordinated comparee nouns ('metal and stone') are modified by an adjective, expressing the parameter ('better'), which itself governs the adjunct expressing the standard of comparison ('from/than

\footnotetext{
${ }^{11}$ According to a native speaker, the converb higg 'passing' could be dropped without a change in meaning.

${ }^{12}$ Including verbs accompanying ideophonic parameters.

${ }^{13}$ Treis (2012) provides more information on negative relative verbs (participles).
} 
wood') (cf. (23-i)). The comparee nouns in (24) are marked for the nominative case because they function as the subject of dagámmee ' $(3 \mathrm{~m})$ is found'.

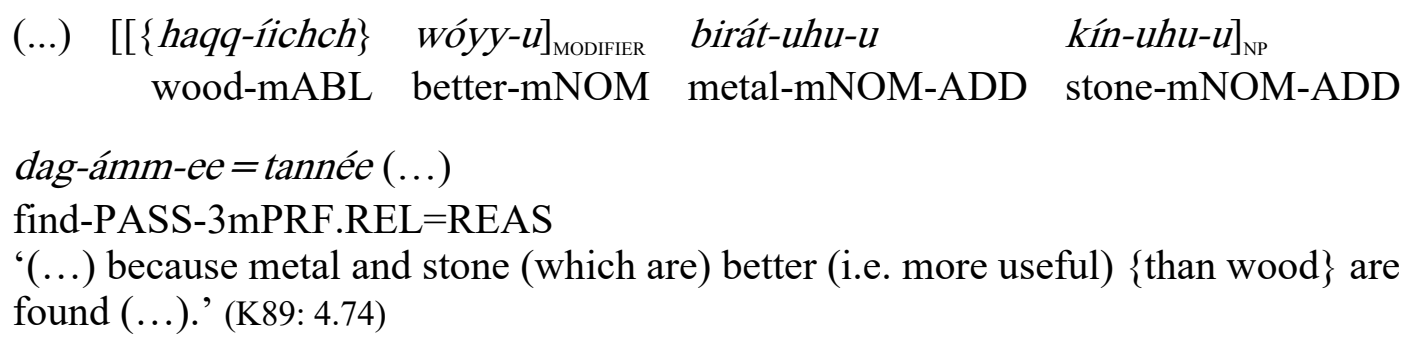

In (25), the noun expressing the comparee ('poem') is the object of xáaf'Write!' and requires the accusative case in this function. The preceding modifier phrase contains a negative relative verb expressing the parameter of comparison, which itself governs the standard noun phrase ('from/than ten lines') as an adjunct.

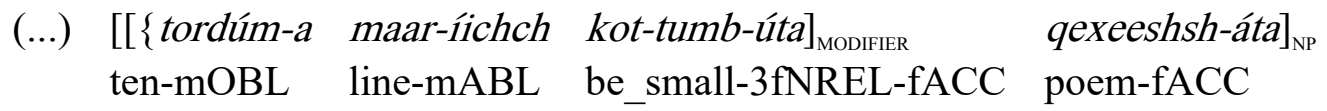

xáaf

write.2sIMP

'(...) write a poem (which is) not shorter $\{$ than ten lines $\} . '$ (K89: 5.35)

The attributive comparative construction becomes fairly complex when the standard of comparison in the modifier phrase is again modified. In (26), the standard taméech 'from/than the use' is preceded by the genitive noun daabb-ó 'of bread', which is itself modified by two coordinated genitive nouns ('of wheat and oats') and a relative clause ('which is very common in Ethiopia').

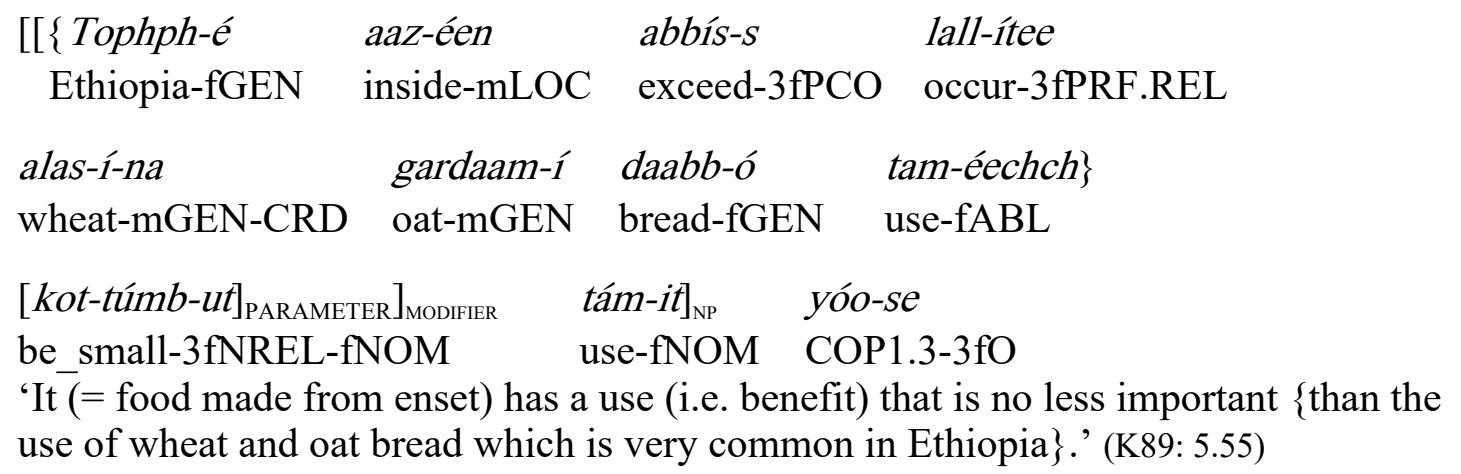

\subsection{Comparison of absolute superiority}

For the expression of absolute superiority (superlativity), we find two different superlative constructions in Kambaata. One has an ablative-marked universal quantifier as the standard of comparison; the other has a locative standard of comparison. Most commonly, the standard phrase precedes the comparee phrase. The English paraphrases are as follows:

(27) (i) Ablative superlative construction: 'From all (X), A is good.' 
(ii) Locative superlative construction: 'Among X, A is good.' 14

These constructions are considered semantically equivalent by native speakers; they may, however, have pragmatic differences that remain to be explored.

\subsubsection{Ablative superlative construction}

The ablative superlative construction is built on the model of that expressing relative superiority (see $\S 3.1$ ); the only difference concerns the choice of the standard of comparison, which is either the universal quantifier horá 'all' (28a) or a numeral quantifier (28b) that specifies the number of members in the set with which the comparee is compared. The individual standard of comparison of the comparative construction is replaced by a standard denoting the entire set of possible individuals in the superlative construction.
a. $\quad\{$ Hor-íichchi- $n\}$
gabbánch-u-S
áy-ee-t?
all-mABL-N short-mNOM-DEF who-mNOM.VV-COP3
'Who is the shortest? (lit. \{From all, \} the short (one) is who?)' (K89: 2.79)
b. Agánn-u $\quad$ sas-íichchi-ssa- $n\}$ gabbánch-u-a
PN-mNOM three-mABL-3pPOSS-N short-mPRED-mCOP2
'Aganno is the shortest of the three of them (lit. short \{from the three of them\}).'
(K89: 2.79)

The quantifier can also be used as a modifier in the standard phrase, as in (29) where the head of the standard phrase is the nominalising enclitic $=r$ 'ones, thing(s)'.

$$
\begin{aligned}
& \{\text { Hór-aa }=r \text {-íichchi-n }\} \quad \text { abbíshsh } \\
& \text { all-mOBL=NMZp-mABL-N exceed.3mPCO } \\
& \text { kichche'-ishsh-o-'ée-hu m-á agújj-ee-he? } \\
& \text { be sad-CAUS-3mPFV-1sO.REL-mNOM what-mACC seem-3mPRF-2sO } \\
& \text { 'Which incidence do you think has made me saddest? (lit. \{From all things, \} the one } \\
& \text { that has made me very sad seems (to be) what to you?)' (K89: 6.124) }
\end{aligned}
$$

A morpheme - $n$ of a yet undetermined pragmatic function - and hence just glossed " $N$ " - is obligatorily added phrase-finally after the ablative morpheme of the standard NP in the superlative construction; cf. (28)-(29). While this - $n$-morpheme is also found in other contexts, ${ }^{15}$ it is to be noted that the standard in the comparative construction of relative superiority $(\$ 3.1)$ is not combined with this morpheme except in the following grammatically determined context: If the standard of comparison contains a disjunction, the conjunct preceding $i k k o$ obligatorily co-occurs with the $-n$-morpheme (30). Note, however, that the connector $i k k o$ triggers the occurrence of $-n$ in all contexts, i.e. even outside of the comparative construction. More work is still required on the

\footnotetext{
${ }^{14}$ I have chosen 'among X' as the literal translation of the locative-marked standard. Given that the Kambaata locative expresses a vague locative relation, I could have also chosen 'in X', 'on X' or 'at X'.

${ }^{15}$ The $-n$-morpheme is frequently found on nouns and pronouns of all cases except the genitive, on modifying and predicative adjectives and numerals, and on subordinate verb forms. There are even instances where it is attested on main verbs (for a preliminary analysis see Treis 2008: 220-27).
} 
functional range of $-n$, which is simply labelled an "emphasis marker" by Schneider-Blum (2007) in Alaaba, Kambaata's closest relative.

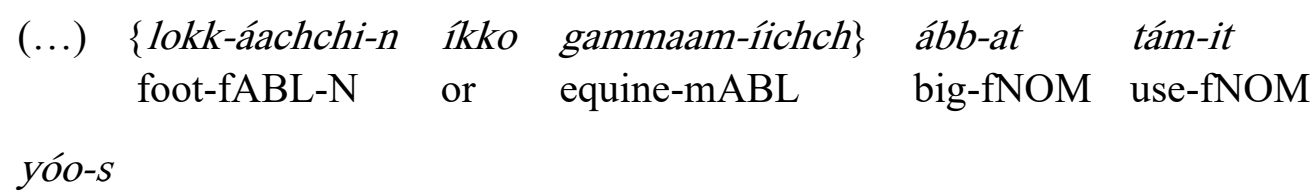

COP1.3-3mO

'(They) are of better use \{than feet or equines\} (...).' (K89: 5.55)

Kambaata's primary superlative construction, in which the standard is expressed by a universal quantifier, belongs to the cross-linguistically most widespread Type A (Absolute Comparison Superlatives) in Gorshenin's typology (2012: 83).

\subsubsection{Locative superlative construction}

Whereas the ablative superlative construction (\$3.2.1) is widely attested in my corpus, the locative type is less common. Two instances are attested in a mock dialogue, on the basis of which I was able to elicit several additional examples; two other examples were overheard, and one example was found in a local publication. The ablative superlative construction (\$3.2.1) can be considered a sub-type of the comparative construction ( $\$ 3.1)$. In contrast, the locative superlative construction is not directly formally related to the comparative. Instead, it is a simple positive construction, i.e. non-comparative qualifying construction, extended by a locative adjunct. The locative standard qophphan-áan 'among lies' in (31) refers to the totality of lies from which the comparee, isé=bii 'hers (i.e. her lie)', is singled out and to which it is compared. Another superlative construction with a locative standard is given in (32). The ablative and locative superlative types do not only differ with respect to the case marking on the standard NP but the locative type also lacks a universal or numeral quantifier.

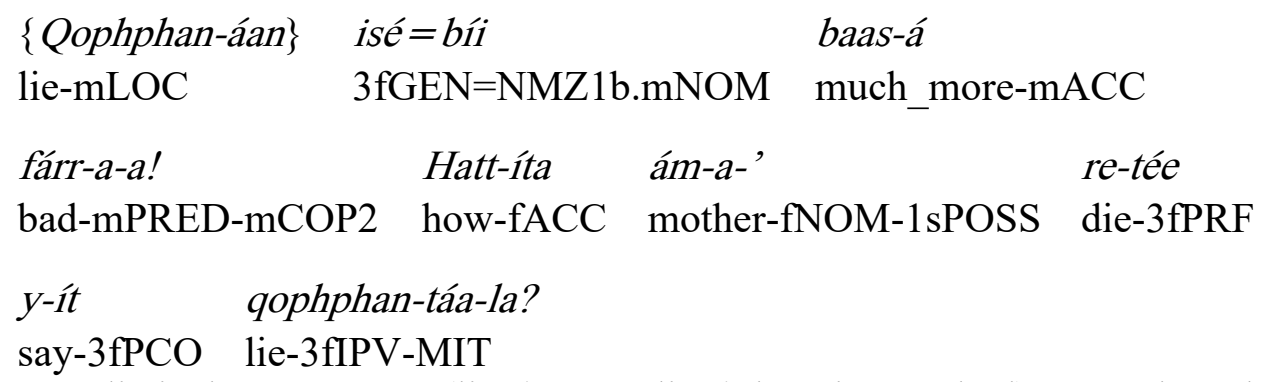

'Her lie is the worst ever (lit. \{among lies, \} hers is very bad)! How dare she say that her mother has died (lit. How dare she lie, saying: 'My mother has died.')?'

[DW_Simulation Market Dialogue_2014-12-24] 


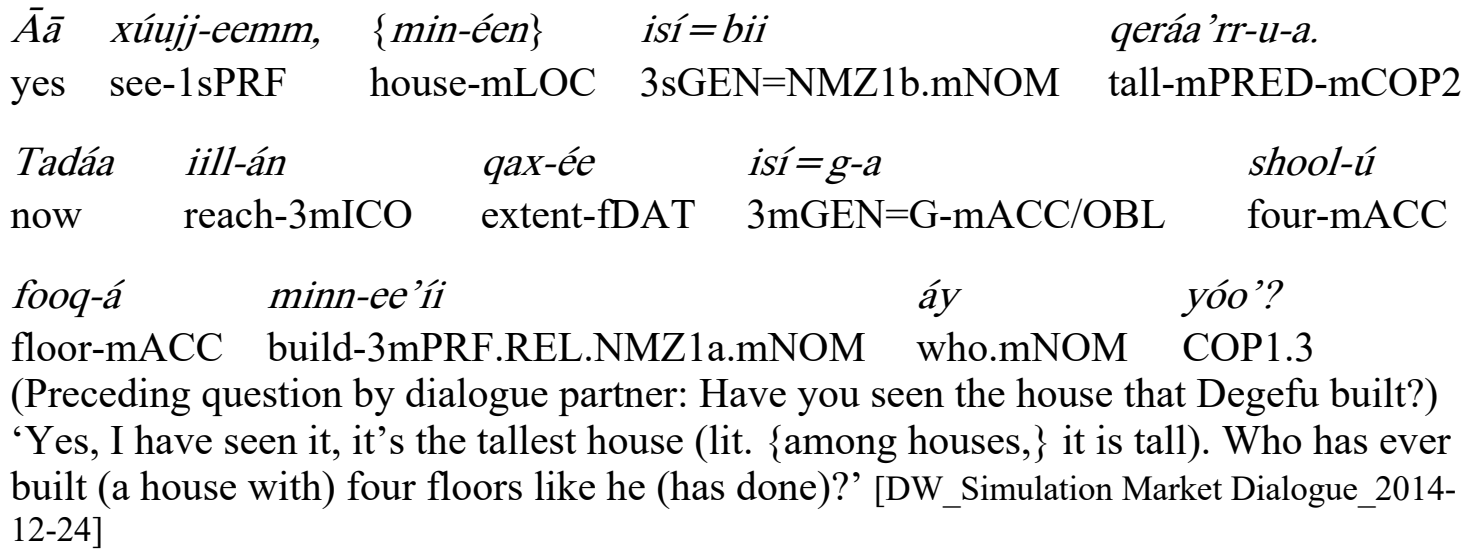

A native speaker confirmed that qophphanáan 'among lies' (31) and minéen 'among houses' (32) could be replaced by ablative standards plus a universal quantifier (\$3.2.1), i.e. qophphaniichch horiichchin 'from/than lies' and miniichch horiichchin 'from/than all houses', respectively.

Ex. (33) is taken from a local Kambaata publication on oral literature; ex. (34) was overheard.
\{Haqq-áan\}
fărr- $u$
m-áha-a-n?
Undulúmm-a-a

wood-mLOC bad-mNOM what-mPRED-mCOP2-Q mortar-mPRED-mCOP2

'What is the worst wood(en thing) (lit. Among wood, the bad is what?) - The mortar.' (Geetaahun 2002: 152)

\begin{tabular}{|c|c|c|}
\hline $\begin{array}{l}\text { Haqq-áan\} } \\
\text { ood-mLOC }\end{array}$ & $\begin{array}{l}\text { fárr- } u \\
\text { bad-mNOM }\end{array}$ & $\begin{array}{l}\text { tontóon-a-a, } \\
\text { plant_species-mPRED-mCOP2 }\end{array}$ \\
\hline $\begin{array}{l}\{\text { cii'-áan }\} \\
\text { birds-fLOC }\end{array}$ & $\begin{array}{l}\text { färr- } u \\
\text { bad-mNOM }\end{array}$ & $\begin{array}{l}\text { hagás-oo-t, } \\
\text { wattled_ibis-mNOM.VV-COP3 }\end{array}$ \\
\hline ple-mLC & $\begin{array}{l}\text { fărr- } u \\
\text { bad-mNON }\end{array}$ & $\begin{array}{l}\text { ebál-oo-t } \\
\text { PN-mNOM.VV-COP3 }\end{array}$ \\
\hline
\end{tabular}

(Context: Speaker A mentions the creeper tontoona in a conversation, which makes Speaker B recite a mock poem) 'The worst tree is the [smelly] tontoona-creeper, the worst bird is the wattled ibis, [and] the worst person is So-and-so.' [overheard]

Unlike the comparative construction (\$3.1) and the ablative superlative construction $(\S 3.2 .1)$, the locative superlative construction has a rigid word order. As seen in all attested examples, the standard of comparison always precedes the comparee. Permutations tests have shown that the superlative interpretation is lost if the order of standard and comparee is reversed (35)-(36).
\{Kambaat-í hegeeg-óon\} Angácc-u gíd-a-a
PN-mGEN area-mLOC PN-mNOM cold-mCOP2
'Angacca is the coldest area of Kambaata.' [Speaker judgment: Expression of highest degree] [Elicited] 
Angácc-u $\quad$ Kambaat-í hegeeg-óon $\}$ gíd-a-a

PN-mNOM PN-mGEN area-mLOC cold-mCOP2

'Angacca is a cold place in the Kambaata area.' [Speaker judgement: Not necessarily the coldest place] [Elicited]

Kambaata's secondary superlative construction, in which the scope is expressed in a locative adverbial phrase and marked by a morpheme not used as a standard marker in the comparative construction, belongs to Type S[cope] Superlative of Gorshenin's (2012: 111f) typology.

\subsubsection{Attributive superlative construction}

Kambaata has an attributive superlative construction in which all components of the comparison (comparee, standard and parameter) are found inside one NP. In (37), the comparee kasalá 'charcoal' is the direct object of áffeemm 'I have grabbed (i.e. I have)'. In the comparee NP, of which kasalá is the head, we find a modifier consisting of the adjective danaam-ú 'good', expressing the parameter of comparison, and the universal standard hor-íichch-in 'from all'.

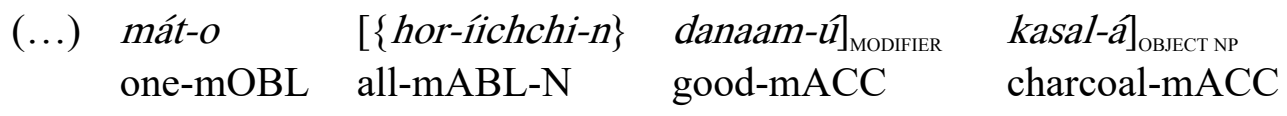

\begin{tabular}{|c|c|c|c|}
\hline áff-eemm & y-áyуоoо & manch-íin & $y$-éemm \\
\hline grab-1sPRF & say-3mPROG.REL & man.SG-mICP come_across.IDEO & say-1sPFV \\
\hline
\end{tabular}

Adjectives can be used as heads of NPs without being nominalised, as the use of fayy- $\dot{a}$ 'healthy' in (38) illustrates. The referent with the quality expressed by the adjective is determined by the (extra-)linguistic context.

$$
\begin{array}{ll}
\text { Fayy-á } & \text { aaqq-itéent } \\
\text { healthy-mACC } & \text { take-2sPRF }
\end{array}
$$

'You took the healthy one (understood from the context: healthy child).' [TH_2003-05-28]

Hence, we also find examples in which the comparee of an attributive superlative construction is retrievable from the context and thus omitted. In (39), the adjective kee 'mmáashsh-u '(the) heavy (ones)' has become the head of the NP from which the comparee was dropped.

\section{(39) $\left[\{\right.$ Ka'llixx-1́ichch hor-1́ichchi-n $\}$ kee'mmáashsh-u $\left.u_{\text {PARAMETER }}\right] \quad \varnothing_{\text {COMPAREe }}$ accident-mABL all-mABL-N heavy-mNOM \\ makín-i-a ka'llíxx-a \\ car-mGEN-mCOP2 accident-mPRED \\ 'The most dangerous accidents are car accidents (lit. \{From all accidents, $\}$ the heavy (ones) are car accidents).' (K89: 4.106)}

Attributive superlative examples with a locative standard NP (\$3.2.2) are not (yet) attested in recorded or written data. Elicitation confirmed, however, that they are possible (40). 

$\{$ Woqq-áan
orc-áam-u
Woqq-óo
Duuráam-e-a
road-mLOC mud-AAM-mNOM road-mNOM PN-fGEN-mCOP2

'The muddiest road is the Durame one (lit. \{Among the roads, \} the muddy one is the one of Durame).' [Elicited]

\subsection{Comparison of inferiority}

Kambaata does not have a grammaticalised or conventionalised comparative construction of inferiority. In order to express that someone has a quality to a lesser degree than somebody else, periphrases with the inchoative-state verb kot- 'be(come) not enough, less, insufficient, small, decrease' are possible but rarely attested in my database (41).
Handis-ó dúub-u
$\{$ hiz-ee-sí= hann-1ichch $\}$
PN-mGEN wealth-mNOM
brother-mGEN-3mPOSS=NMZ2-mABL

qah-ú $<n>k a \quad$ kot-áno

small-mACC $<\mathrm{N}>$ be small-3mIPV

'Handiso's wealth is a little less \{than his brother's $\}$ (i.e. Handiso is a little less rich than his brother).' (K89: 3.17)

Instead, inferiority is expressed by negative equative constructions (§5) (42)-(43).

\section{Hór-a-ni-i! Haláab-u Hoosaan-í qax-á qee’rr-áno-ba'a} all-mOBL-L-ADD PN-mNOM PN-mGEN extent-mACC be far-3mIPV-NEG1 'Not at all! Alaaba is not as distant as Hosaina.' [Intended translation target: '... Alaaba is less distant than Hosaina.'] [Elicited]

$\begin{array}{llll}\text { IS-óoni- } n & \text { béet-u-SSa } & y \text {-eennó } & \text { qax-á } \\ \text { 3m-mLOC-N } & \text { child-mNOM-3pPOSS } & \text { say-3mIPV.REL } & \text { extent-mACC }\end{array}$

kaa'll-im-bá-ssa

help-3mNIPV-NEG1-3pO

(Context: Now the couple is old, and they cannot cultivate their land any longer.) 'On top of that, their son doesn't help them as much as expected (lit. as much as one says).' [Intended translation target: '... their son helps them less than expected.'] [Elicited]

\section{Comparison of similarity}

A similative construction is a type of comparison construction expressing equal manner or quality between a comparee and a standard of comparison (Haspelmath \& Buchholz 1998, Fuchs 2014). Kambaata marks the standard of similative comparison by an enclitic multifunctional morpheme $=g$ (gloss: $\mathrm{G})$; the standard is a genitive modifier to $=g(44)$. 


\begin{tabular}{|c|c|c|c|}
\hline$A ́ n$ & $\{$ qurxummeem-á $=g-a\}$ & waachch-ú & dand-eemmí $=d a$ \\
\hline $1 \mathrm{sNOM}$ & fish-fGEN=G-mACC/OBL & swim-mACC & be_able-1sPFV.REL $=$ COND \\
\hline 1-á & ih-áno & & \\
\hline & be-3mIPV & & \\
\hline
\end{tabular}

The standard phrase is an adverbial modifier to the predicate. It consists minimally of a genitive noun plus $=g$; the enclitic is itself case-marked; see $-a \mathrm{ACC} / \mathrm{OBL}$ in (44). The double case-marking in the standard phrase - once on the semantic head, once on the standard marker $=g-$ points to a nominal origin of the enclitic. The standard marker $=g$ is in fact a manner nominaliser. Before proceeding with the analysis of the similative construction ( $\$ 4.4)$, information on the historically primary function of $=g$ as a manner nominaliser is provided in $\S \S 4.1-4.3$. Treis $(2017 \mathrm{~b})$ gives a more detailed account of the multifunctionality of $=g$, which is used, among others, as a marker of complement clauses (85), purpose clauses and temporal clauses of immediate anteriority ('as soon as').

\subsection{The morphology of the manner nominaliser $=g$}

The morpheme $=g$ belongs to a group of enclitic nominalisers including $=b$ 'place' (45), $=b i i(-t a)$ NMZ1b 'one (m/f)' (31)-(32), =hann NMZ2 'one (m)' (2), =tann NMZ2 'one (f)' and =r NMZp 'thing(s), ones' (7), (29), all of which are of (pro)nominal origin and take modifier phrases, i.e. genitive (pro)nouns, inflected adjectives and relative clauses rather than roots or stems as their input. ${ }^{16}$

$$
\begin{aligned}
& l a l-\hat{\imath}=\boldsymbol{b}-\boldsymbol{a} \\
& \text { cattle-mGEN=PLACE-mACC }
\end{aligned}
$$

'(the) place of (the) cattle, (the) cattle-place'

$$
\begin{array}{ll}
l a l-1=g-a & \text { '(the) manner of (the) cattle, } \\
\text { cattle-mGEN=G-mACC/OBL } & \text { the cattle's way of doing things' }
\end{array}
$$

The case marker following the nominalisers is not fixed but dependent on the syntactic function and the semantic role of the phrase in the clause, e.g. the ACC/OBL-marking $-a$ on the standard phrase in the similative construction in (44) is due to its adverbial function. The morpheme $=g$ is inherently masculine (see the gloss of the case/gender portmanteau suffix with which it combines) and inflects almost like a full noun (Table 3).

\footnotetext{
${ }^{16}$ Treis (2008: 285ff, 379f, 388f) provides information on the exceptional cases where the manner morpheme is added to a demonstrative root and where it thus has characteristics of a derivational morpheme rather than a phrasal enclitic.
} 


\begin{tabular}{|c|c|c|c|c|}
\hline & $\begin{array}{l}=g(\mathrm{~m} .) \\
\text { 'manner' }\end{array}$ & \multirow{10}{*}{4} & $\begin{array}{l}\text { dum-á (m.) } \\
\text { 'back room' }\end{array}$ & $\begin{array}{l}\min -1 ́(\mathrm{~m} .) \\
\text { 'house' }\end{array}$ \\
\hline $\mathrm{ACC}$ & $=g-a$ & & dum-á & min-í \\
\hline NOM & $=g-u$ & & dúm-u & mín-u \\
\hline GEN & $=g-i ́ i$ & & dum-í & min-í \\
\hline DAT & $=g-i ́(-h a)$ & & dum-íi(-ha) & min-íi(-ha) \\
\hline ABL & $=g$-íichch & & dum-íichch & min-1ichch \\
\hline ICP & $=g$-íin & & dum-íin & min-íin \\
\hline LOC & = g-áan & & dum-áan & min-éen \\
\hline OBL & $=g-a$ & & dúm-a & mín-e \\
\hline PRED & $=g-a$ & & dúm-a & mín-i \\
\hline
\end{tabular}

Table 3. Case paradigm of $=g$ compared to that of masculine full nouns

The case paradigms of $=g$ and the noun $d u m$ - $a$ 'back room', a masculine noun of the $-\dot{a}$-declension, are almost identical. ${ }^{17}$ The $=g$-morpheme only lacks a difference between the accusative and oblique case (the syncretic form is glossed ACC/OBL), which is a type of syncretism not attested for any other nominal declension. ${ }^{18}$ While the vast majority of masculine nouns distinguish between eight cases, the $=g$-morpheme distinguishes only between seven. Another small difference concerns the genitive form, which is a long $-i i$ for the manner morpheme but a short $-i$ for nouns of the $-\dot{a}$-declension. The equal sign indicates that the enclitic $=g$ is phonologically and syntactically dependent on a host. It is stressless in certain cases and can never be used in isolation.

\subsection{The manner nominalising function of $=g$}

The $=g$-morpheme is attached to any type of modifier phrase and generates nominalised phrases that are translatable as 'manner/way of [(pro)noun]' (47), '[adjective] manner/way' (48)-(49), or 'manner/way that [relative clause]' (50). The resulting manner phrases can assume any syntactic function and any semantic role in the clause. Ex. (47) contains two manner-nominalised phrases, the subject noun phrase Sabir- $\dot{o}=g-u$ 'Sabiro's way' and the ablative-marked adverbial noun phrase Shaameeb-í=gíichch 'from/than Shaameebo's way'.
$\{$ Shaameeb-í=g-íichch $\}$
$\{$ Sabir-ó $=g-u\}$
wóyy-a-a
$\mathrm{PN}-\mathrm{mGEN}=\mathrm{G}-\mathrm{mABL}$
$\mathrm{PN}-\mathrm{mGEN}=\mathrm{G}-\mathrm{mNOM}$
better-mPRED-mCOP2
'Shaameebo's way (of doing things) is better than Sabiro's way (lit. \{From Sabiro's way, $\{$ Shameebo's way\} is better).' [Elicited]

Apart from genitive (pro)nouns, the manner nominaliser takes adjectival phrases as input. Most frequently, $=g$ is used with the adjectives 'good', i.e. danáam- $o=g(g)-a$ 'well, in a good way' (49),

\footnotetext{
${ }^{17}$ See Treis (2008: 103) for an overview of the nine feminine and twelve masculine nominal declensions.

${ }^{18}$ The ACC and the OBL forms cannot be differentiated if the case marker is the last morpheme of the word. However, the presence of additional suffixes, e.g. the pragmatically determined morpheme $-n$, causes a distinction to surface again between the ACC and OBL forms, which was presumably made in an earlier stage of the language. The combination of $=g-a$ OBL and $-n$ results in $=g-a-n$ (67). In contrast, in the ACC case, the $-n$ is infixed into the older, non-eroded ACC form $=g$ - $a h a$, which results in $=g$-anka (59).
} 
and 'bad', i.e. fárr $-a=g(g)-a(48)$ and híll- $a=g(g)-a$ 'badly, in a bad way'. Apart from these three adjectives, $=g$ is attested in 14 other adjectives in the Kambaata schoolbooks (K89).

$\mathrm{Ku}$ hegéeg- $u \quad\{$ fárr-a $=g g$-a $\} \quad$ fooshsheeh-áyyoo'u

A_DEM1.mNOM area-mNOM bad-mOBL=G-mACC/OBL smell-3mPROG 'This area smells $\{$ in a bad way/badly $\}$. ' [Elicited]

$\begin{array}{llll}\text { Ta } & \text { huj-íta } & \text { hujat-íi } & \text { kann-íichch } \\ \text { A_DEM1.fACC } & \text { work-fACC } & \text { work-mDAT } & \text { P_DEM1m-mABL }\end{array}$

$\{$ danáam- $u=g g-u\} \quad$ yóo-ba'a good-mNOM=G-mNOM COP1.3-NEG1

'There is no better way than this (one) to do the work (lit. There is no \{good way\} from this (one) to do the work).' [Elicited]

In Kambaata, modifying adjectives always agree with their head noun (Treis 2008: 88-93) - and thus with the manner nominaliser - in case and gender. The oblique case of the adjective in (48) and the nominative case of the adjective in (49) are triggered by the accusative/oblique and the nominative case markers of the enclitic $=g$, respectively. ${ }^{19}$ As seen in (47)-(49), the manner morpheme is realised either as a single $=g$ or a geminate $=g g$ in free variation. The geminate $=g g$ is a frequent variant of $=g$ when the stress falls on the penultimate syllable of the host.

Finally, the manner nominaliser takes clausal inputs; more precisely, it is added to modifying (relative) clauses. The nominalised entity is used in object function in (50).

$$
\begin{aligned}
& \text { (...) \{mat-íta zar-án-tee oddishsh-áta } \\
& \text { one-fACC tear-PASS-3fPRF.REL clothes-fACC } \\
& \text { gob-baantí }=g-a\} \quad \text { kúl } \\
& \text { sew-2sIPV.REL=G-mACC/OBL tell.2sIMP } \\
& \text { 'Explain (lit. tell) \{the way in which you mend torn clothes\} (...)!' (K89: 6.74) }
\end{aligned}
$$

\subsection{The nominal origin of the manner nominaliser $=g$}

Even though $=g$ is no longer used as an independent word, it is very likely that $=g$ goes back to a fully-fledged noun 'manner, way of doing something'. The original form is, however, unknown. Sidaama, a closely related HEC language, has a noun gara $(\mathrm{m}$.$) 'manner, way of doing something'$ (Gasparini 1983: 114, Kawachi forthcoming), whose Kambaata cognate may have served as the source for $=g$. The nominal origin of $=g$ is reflected in its case-marking potential (Table 3). It can also host morphemes that are found on regular nouns, e.g. the additive morpheme 'also, too' (ADD) (51), the interrogative -'nnu-morpheme 'and what about?', and the pragmatically determined - $n$-morpheme $(\mathrm{N})(59)$.

\footnotetext{
${ }^{19}$ Cardinal numerals and demonstratives, which are also case/gender-agreeing modifiers, cannot be the input of the manner nominalisation. Native speakers reject as ungrammatical forms such as *lám- $u=g g-u$ two-mNOM=G-mNOM 'two ways' or $* k u=g-u$ A_DEM1.mNOM=G-mNOM 'this way'. It is, however, possible to add the manner nominaliser to ordinal numerals, e.g. woná $=g-u$ 'the first way' (NOM), lanki $i=g-u$ 'the second way' (NOM) etc. Ordinal numerals do not show case/gender-agreement; they share features of genitive nouns (for details see Treis 2008: 236f, 313ff; 2017a).
} 


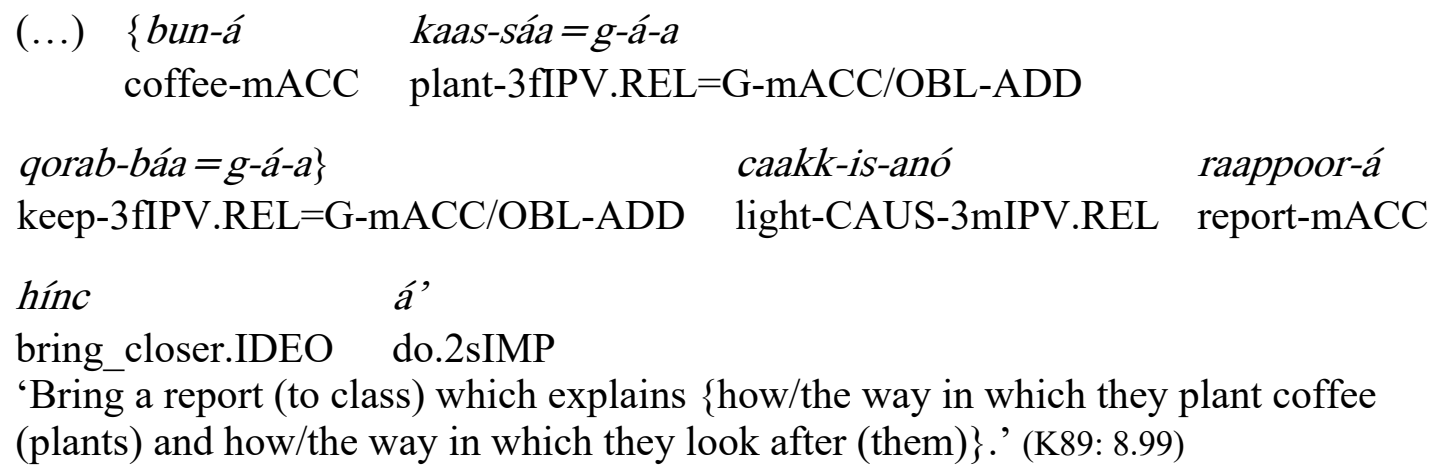

The position of the copula in non-verbal clauses provides further evidence for the nominal origin and status of $=g$. In (52), the manner nominalisation (in curly brackets) is the predicate; the headless, nominative-marked relative clause is the subject. The masculine gender allomorph of the non-locative copula $-a(\mathrm{mCOP} 2)$ is triggered by the masculine gender of $=g$.

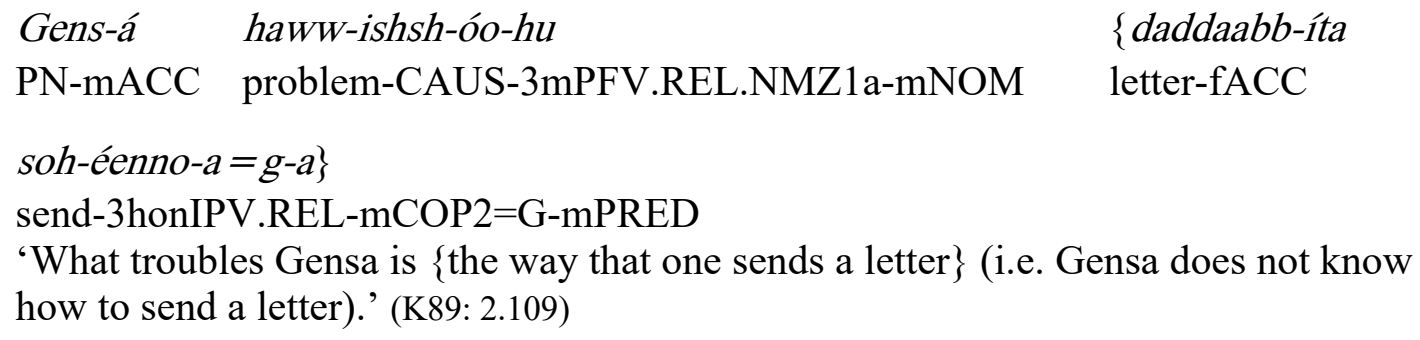

According to a general syntactic rule in Kambaata, the non-locative copula (COP2) is found after derivational and inflectional morphemes towards the $\mathrm{end}^{20}$ of the predicate if the predicate consists of a single morphological nominal word. It shifts to the preceding word if the predicate is modified by a genitive noun, adjective, numeral or relative clause (Treis 2008: 414f). In (49), the copula is found predicate-medially, in other words, on the relative modifier - which is evidence that the manner nominalisation is still considered a multi-word noun phrase consisting of a modifier and a head noun rather than a single morphological word.

\subsection{Predicative similative construction}

Returning to the similative construction, this section discusses how comparee and standard of comparison are marked morphologically and which syntactic functions they can assume. The focus here is on the predicative construction with a phrasal standard of comparison (53). See $\S 4.5$ for the attributive construction and $\$ 4.6$ for the predicative construction with a clausal standard of comparison.

\footnotetext{
${ }^{20}$ The copula can still be followed by possessive, coordinative and pragmatically determined suffixes.
} 
(53) Predicative similative construction

\begin{tabular}{|c|c|c|c|}
\hline $\begin{array}{l}\text { Comparee } \\
\text { GENDER }_{\mathrm{i}} /[\text { Case }]\end{array}$ & $\begin{array}{l}\text { \{Standard } \\
\text { GENDER }_{\mathrm{j}} / \mathrm{GEN}\end{array}$ & $\begin{array}{l}=\boldsymbol{g}-\boldsymbol{a} \boldsymbol{}_{\text {STANDARD NP }} \\
=\text { manner-mACC/OBL }\end{array}$ & [Verb] \\
\hline ANY SYNTACTIC FUNCTION & $\begin{array}{l}\text { MODIFIER OF } \\
\text { STANDARD MARKER }\end{array}$ & STANDARD MARKER & PR \\
\hline
\end{tabular}
$\{$ Adan-ch-ó $=g-a\}$
gá'l-a
agg-óomm
cats-SG-mGEN=G-mACC/OBL shard-mOBL drink-1sPFV
'I drank from a shard \{like a cat\}.' [TH_Proverbs2003]
$\{$ Xabar $-1=g-a\}$
bínn
$y-\hat{1}$
ashes-mGEN $=\mathrm{G}-\mathrm{mACC} / \mathrm{OBL}$ disperse.IDEO say-2sIMP

(Curse) 'May you be dispersed \{like ashes\}!' [AN2016-02-19_002]

The standard of comparison is an adverbial phrase to the predicate. The standard marker $=g$ is always followed by an ACC/OBL case morpheme in the similative construction, not only in (54)(55) but in all the examples in my corpus. Whereas the syntactic function of the standard of comparison is set, the comparee occurs in different syntactic functions. In (54)-(55) the comparee is the subject of the clause and as such it is marked by subject agreement on the verb; see $1 \mathrm{~s}$ in (54) and $2 \mathrm{~s}$ in (55). In contrast, the comparee ha'mmichchús 'enset corm' functions as the direct object in (56): 'One boils the enset corm like (one boils) potatoes'. But not: *'One boils the enset corm like potatoes (boil the enset corm)'.

\begin{tabular}{|c|c|c|}
\hline $\begin{array}{l}\text { Ha'mm-ichch-ú-s } \\
\text { enset_corms-SG-mACC-DEF }\end{array}$ & $\begin{array}{l}\{\text { danekk-á }=g-a\} \\
\text { potato-fGEN=G-mACC/OBL }\end{array}$ & $\begin{array}{l}\text { gaf-éen } \\
\text { boil-3honPCO }\end{array}$ \\
\hline$\dot{a}=d a$ & iitt-am-áno-a & \\
\hline
\end{tabular}

In (57), the comparee is the unexpressed indirect object of aass- 'give', namely the children understood from the context. If they had been expressed overtly, they would have been encoded in the dative case. In (58), two possessors, hair and grass, are in a comparee-standard relation.

$$
\begin{aligned}
& \text { (...) zabb-ú áass-u has-is-anóo } \\
& \text { medicine-mACC give-mNOM want-CAUS-3mIPV.REL.NMZ1a.mNOM } \\
& \{\text { géex-aa manní }=g \text {-aa- } n-t\} \\
& \text { adult-mOBL people-mGEN=G-mACC/OBL.VV-N-COP3 } \\
& \text { '( } \ldots \text {.. it is }\{\text { like (to) adults\} that one has to give medicine (to the children).' (K89: 8.130) }
\end{aligned}
$$
Muumm-íi hix-é $=g-a$
xáph-u
yóo-s
hair-mDAT grass-fGEN=G-mACC/OBL root-mNOM COP1.3-3mO
'The hair has roots like grass (lit. There are roots to the hair like (to) the grass).'
(K89: 2.34)

The comparee, plaaneet-áan 'on the planet', is a locative adverbial in (59). 


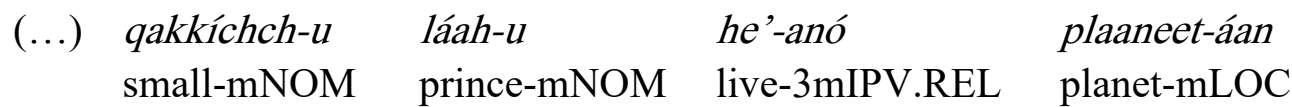

$\{$ wól-o plaaneet-í $=g-a<n>k a\} \quad$ danáam- $u=r r-u-u$

other-mOBL planet-mGEN=G-mACC $<\mathrm{N}>$ good-mNOM=NMZp-mNOM-ADD

färr- $u=r r-u-u \quad$ mut-áno-a

bad-mNOM=NMZp-mNOM-ADD sprout-3mIPV.REL-mCOP2

(...) on the planet where the little prince lived there grew good ones (= plants) and

bad ones (= plants) \{as on other planets\}. (QL 2018)

The comparee can also be a temporal adverbial. Example (60) does not compare the similarity in manner of two entities with respect to a predicate but the similarity of a situation or an event at two different points in time, i.e. this year and last year.
Aní-i
kazammáan- $u$
wóyy-a-a.
$1 \mathrm{sNOM}-\mathrm{ADD}$
this_year-mOBL
better-mPRED-mCOP2
$\{$ Nur-é $=g-a\}$
xíd-at
haww-is-sim-ba-'e
last year-mGEN $=\mathrm{G}-\mathrm{mACC} / \mathrm{OBL}$ pain-fNOM problem-CAUS-3fNIPV-NEG1-1sO
'Me, too, I am better this year. Pain doesn't trouble me (as badly) \{as last year\}.' (K89:
4.125)

To summarise, the invariably ACC/OBL-marked standard phrase gives no indication about which other explicit or implicit noun phrase in the clause is the comparee for which it serves as the standard of comparison.

By definition, similative constructions express sameness of manner (Haspelmath \& Buchholz 1998: 278), whereby manner needs to be understood in a broader sense, i.e. not merely as the techniques, the instruments and the means that are applied and the type of movements (motor patterns) that are carried out. For example, in (54), the compared entities share the same instrument (a shard), and probably also the same technique (licking) and body posture for drinking. In (56), the compared entities share the same means of preparation, namely boiling water. Sameness of manner could also mean that the actions are carried out at the same rate (57) or that the disposition, the attitude or other psychological, social and physical conditions are shared by the compared entities. One can, therefore, argue that the morpheme $=g$ in its function as standard marker in constructions expressing comparison of similarity, as illustrated in the examples in this section, has undergone semantic extension. While $=g$ is a nominaliser of manner in the narrow sense of the word (techniques, instruments, means, types of movement) in the non-comparison examples in $\S 4.2$, the manner encoded by $=g$ in similative constructions embraces the broader sense of the word. The comparee and the standard of comparison may, for instance, have similar properties and possess the same attributes, e.g. in (58) and (59) and they may have a similar shape, habits, needs, intentions, etc. A narrow manner interpretation is often not possible in similative constructions. In (61), the respect in which comparee and standard are similar is left completely open to interpretation. They could, for instance, carry out an action in the same way, to the same extent, with the same goal, or just share a certain physical, psychological, or social quality. 
(61)

Aní-i kii-haa $=g-a<n>k a$

1sNOM-ADD 2sGEN-mCOP2 $=\mathrm{G}-\mathrm{mPRED}<\mathrm{N}>$

'Me, too, I do/am like you.' [Elicited]

\subsection{Attributive similative construction}

All elements of a similative construction may be found in one noun phrase (62).

(62) Attributive similative construction

$\begin{array}{llll}\text { [I }\{\text { Standard } & =\boldsymbol{g}-\boldsymbol{a}\}_{\text {STANDARD NP }} & \text { Verb }]_{\text {MODIFIER }} & \text { Comparee }_{\text {NP }} \\ \text { GENDER }_{\mathrm{j}} / \mathrm{ABL} & =\text { manner-mACC/OBL } & \text { REL } & \text { CASE }_{\mathrm{i}} / \mathrm{GENDER}_{\mathrm{i}} \\ \text { MODIFIER OF } & \text { STANDARD MARKER } & \text { ATTRIBUTE TO } & \text { ANY SYNTACTIC } \\ \text { STANDARD MARKER } & & \text { COMPAREE } & \text { FUNCTION }\end{array}$

In the attributive construction, 'an $\mathrm{X}$ which V-s like a Y', the comparee serves as the head of the noun phrase, see beet- $u$ ' son' in (63), and the standard of comparison, marked by $=g$, is expressed in a relative clause modifying the head noun.

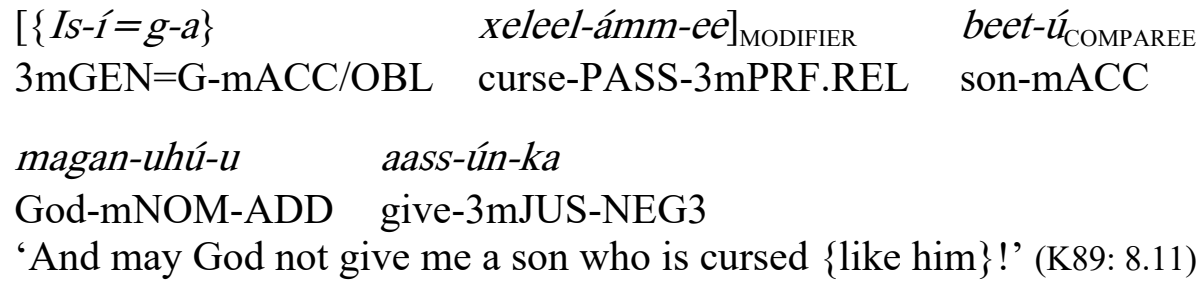

If a 'be' verb is required in the relative clause, 'an X which is like a Y', the locative copula yoo'be located, exist' (COP1) is used. It would be ungrammatical to drop the relative verb yóo in the attributive similative construction in (64), as a standard phrase cannot directly modify a noun (as in English 'there are students like Awwano').

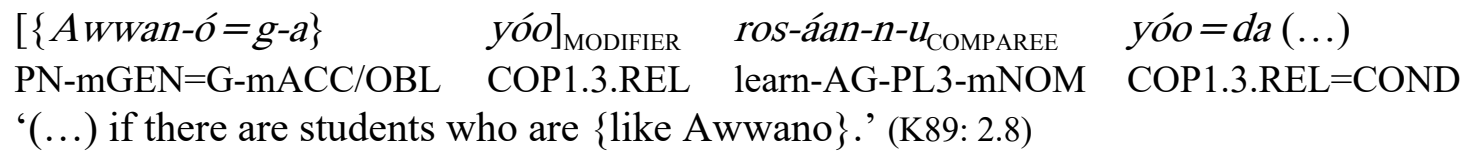

If an attributive similative construction is headless, it is nominalised with a dummy head, e.g. $=r$ 'thing(s), ones', and thus serves to express 'N-like thing(s), N-like one(s)' (65).

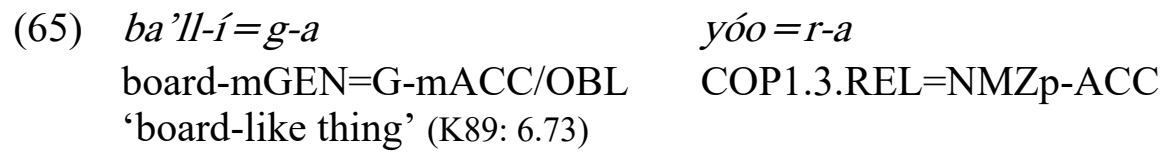

The use of yoo- (COP1) in the attributive similative construction (64)-(65) is especially noteworthy because this copula is otherwise found only in constructions expressing location, existence and possession (Treis 2008: 398-407). Instead of yoo-, one would have expected the use of the verb $i h$ - 'be(come)', which is the fully inflectable verbal substitute of the ascriptive and identificational copulas COP2 and COP3 in subordinate clauses (Treis 2008: 427ff). 


\subsection{Similative clauses}

The standard of comparison is not necessarily a (pro)noun phrase but can also be an entire clause (66)-(67). Similative clauses are relativised clauses plus the standard marker $=g$.

$\begin{array}{lll}\{\text { Mánn-u } & \text { min-i-sí } & \text { am-áta } \\ \text { men-mNOM } & \text { house-mGEN-3mPOSS } & \text { mother-fACC }\end{array}$

sharr-anó $=g-a<n>k a\} \quad$ handar-ití-i sharr-itáa'-indo?

chase_away-3mIPV.REL $=\mathrm{G}-\mathrm{mACC}<\mathrm{N}>$ dove-fNOM-ADD chase_away-3fIPV-Q 'Do doves chase away (their children) \{like men chase away their wives (lit. their mother of the house)\}?' (K89: 8.20)

$\begin{array}{llll}\text { \{Mánn-u } & \text { ayyár-u } & \text { yoo-ba'îi } & \text { hé' } \\ \text { men-mNOM } & \text { air-mNOM } & \text { COP1.3-NEG1.REL.VV } & \text { live.3mPCO }\end{array}$

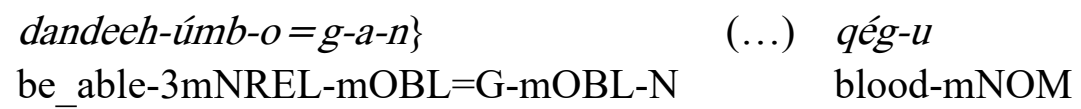

$$
\text { yoo-ba'i=ddá-a he'-íiha dand-áno-ba'a }
$$

COP1.3-NEG1.REL=COND-ADD live-mDAT be able-3mIPV-NEG1

' $\{$ As people cannot survive without oxygen, $\}$ they cannot survive if there is no blood (...).' (K89: 8.100)

Similative clauses are used in a productive idiomatic sentence pattern which expresses that the subjects do something in a way the situation permits them to do it, which is always interpreted as an uncomfortable, unsatisfactory way of doing something (68). In these patterns, the subordinate clause contains a causative form of the verb in the syntactically superordinate clause. The subject of the subordinate clause is only marked by subject agreement on the verb $(3 \mathrm{~m})$ but remains otherwise unexpressed; it can be assumed to be magán- $u$ (mNOM) 'God'. The subordinate verb is in the perfective form in all examples, while the aspect marking in the superordinate clause may vary.
$\{$ Gashsh-ee-'é=g-a\}
gáll-eemm
spend_the_night.CAUS-3mPFV-1sO.REL=G-mACC/OBL spend the night-1sPRF (Question: How was your night? - Possible answer:) 'I passed the night \{as (God) made me pass it\} (i.e in an uncomfortable way).' [Elicited]

\section{Comparison of equality}

By comparison of equality I mean a type of comparison "that ascribes to the comparee the same value of the parameter of comparison as to the standard", as stated by Cuzzolin \& Lehmann (2004: 1213, emphasis mine). In other words, following Henkelmann (2006: 371), a quality is attributed to comparee and standard to an "equal extent". Kambaata distinguishes between two types of equative constructions (69). In the first type, the standard of comparison is dependent on the enclitic nominaliser $=g$ 'manner' $(\S 4)$, in the second type, it is dependent on the noun qax-á 'extent'. 
(69) Predicative equative constructions

(i) Type 1: 'COMPAREE is good in the manner of STANDARD.'

\begin{tabular}{|c|c|c|c|}
\hline mparee & $\{$ Standard & 0 & Parameter \\
\hline $\mathrm{OM}$ & GEN & OBL & $\mathrm{DER}_{\mathrm{i}} / \mathrm{CC}$ \\
\hline & M & ANDARD MARKER & PREDICATE \\
\hline
\end{tabular}

(ii) Type 2: 'COMPAREE is good to the extent of STANDARD.'

\begin{tabular}{|c|c|c|c|}
\hline Comp & \{Standard & (PDP & Parameter \\
\hline GENDER/NOM & G & ext & EN \\
\hline JBJE & $\begin{array}{l}\text { MODIFIER OF } \\
\text { STANDARD M }\end{array}$ & STANDARD MARKER & PREDICATE \\
\hline
\end{tabular}

The manner nominaliser $=g$ has extended its function from a marker of standards of similative comparison (\$4) to a marker of standards of equative comparison (69i). Equative and similative constructions differ only in one respect: In equative constructions the parameter of comparison is overtly expressed by adjectives, inchoative-stative property verbs or ideophones.

The syntax of the two equative constructions in (69) is identical. As in the case of the comparative construction ( 33$)$, the standard phrase is an adjunct to the predicate expressing the parameter; inside the standard phrase the standard marker is the head, while the standard is a genitive modifier (possessor). The comparee is encoded as the subject; it usually precedes the standard NP, but may be shifted into the pre-predicate slot if focussed (cf. \$3.1.1). Both constructions lack a parameter marker. In Henkelmann's typology of equative comparison (2006: 377), they would thus belong to type I.A (comparee and standard in separate NPs, parameter encoded as predicate, explicit EQUAL concept). In Haspelmath et al.'s (2017) typology, the constructions discussed in this section fall under Type 1 ("Only equative standard marker"), which is the most frequent cross-linguistically.

The constructions in (69) differ with regard to their frequency as well as the origin, multifunctionality and degree of grammaticalisation of their respective standard markers. These aspects will be treated in the following sections. Both constructions are attested in spontaneous, written and elicited data.

\subsection{Equative construction with $=g$ 'manner'}

In the first type of equative construction, the standard phrase is marked by the manner nominaliser $=g$, which is added to a genitive-marked standard (pro)noun phrase (70)-(71).

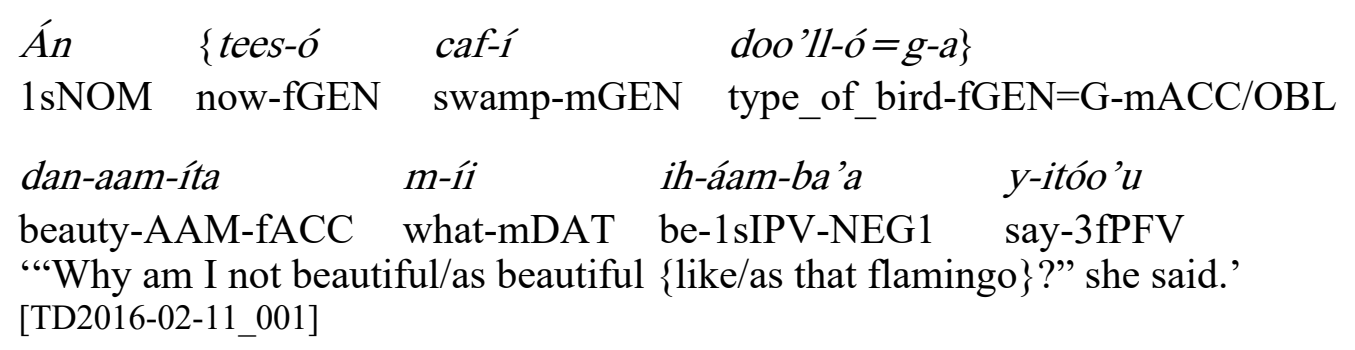


$(71)$
Waaliy-í
máal-u
$\{$ fellee' $-1=$ hann- $1=g-a<n>k a\}$
walia-mGEN
meat-mNOM
goats-mGEN=NMZ2-mGEN $=\mathrm{G}-\mathrm{mACC}<\mathrm{N}>$
xee'nnáashsh-a-a
tasty-mPRED-mCOP2
'The meat of mountain goats is tasty/as tasty \{like/as that of (domestic) goats \}.'

(K89: 5.41)

The nominaliser itself is marked for the ACC/OBL-case and may carry the pragmatically determined morpheme $-n$. In (70)-(71), the parameter is expressed by an adjective, and in (72) by a property verb.

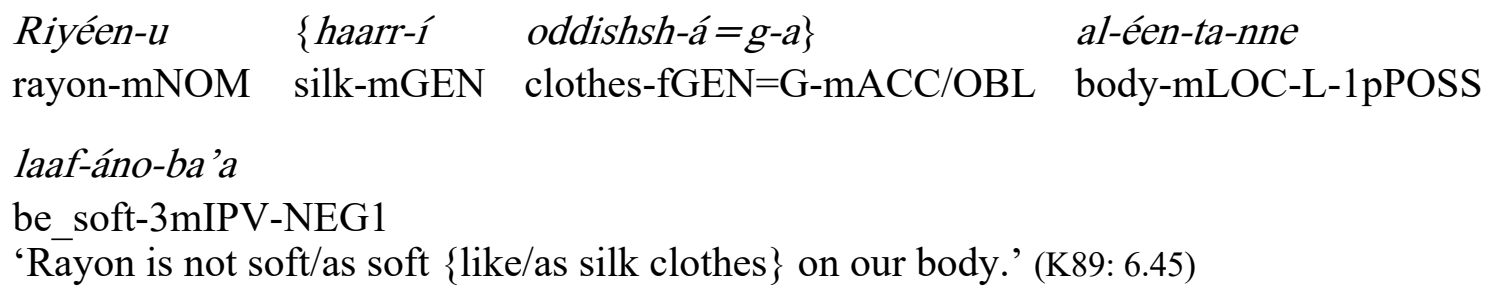

In (73), the adjectival parameter xalig-á 'strong' is the predicate of a subordinate conditional clause and combines with a 'be(come)'-verb, which carries subject agreement and subordinating morphology. If the parameter was a property verb or a property ideophone accompanied by a support verb, it could itself carry the morphology required of predicates in subordinate clauses.

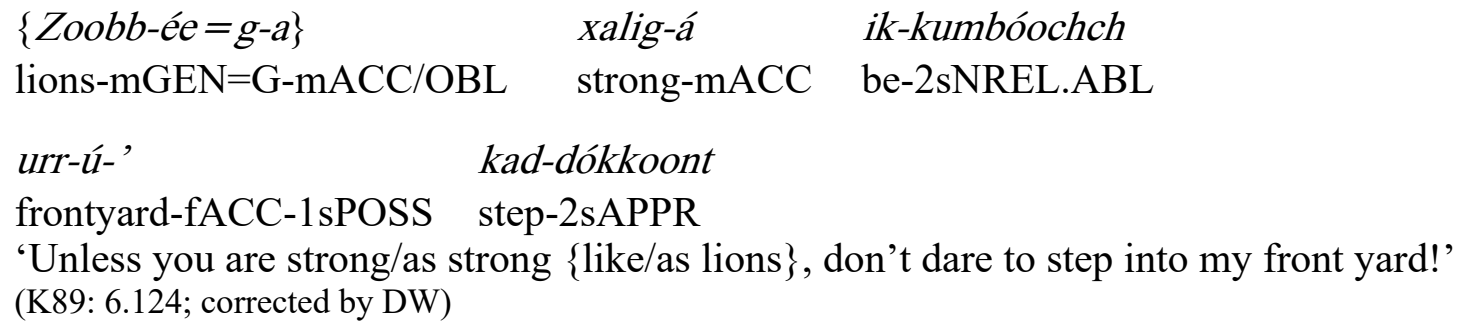

In attributive equative constructions, all components of the comparison (comparee, standard and parameter) are found inside one NP. In (74), the comparee billaww- $a$ 'knife' is the head of the object NP of the clause. It is modified by an adjectival parameter iphph-á 'sharp', which is preceded by the $=g$-marked standard phrase in adverbial function.

$$
\begin{array}{llll}
\{\text { Kí }=\text { hann- } 1=g a<n>k a\} & \text { iphph-á } & \text { billaww-á } & \text { hi'rr-áamm } \\
\text { 2sGEN=NMZ2-mGEN=G-mACC }<\mathrm{N}> & \text { sharp-mACC } & \text { knife-mACC } & \text { buy.MID-1sIPV } \\
\text { 'I will buy a knife (that is) sharp/as sharp }\{\text { \{like/as yours\}.' [Elicited] } &
\end{array}
$$

Examples in which the clausal standard of an equative construction is marked by $=g$ are not attested in my database; see instead $§ 5.2 .3$. 


\subsection{Equative construction with $q a x-a$ ' 'extent'}

In the second type of equative construction, the standard phrase consists of the accusative-marked noun qax-á 'extent', which is preceded by a genitive modifier expressing the standard of comparison; see Da'llis-ó 'of Da'lliso' (2sGEN) in (75) and isé 'her' (3fGEN) in (76).

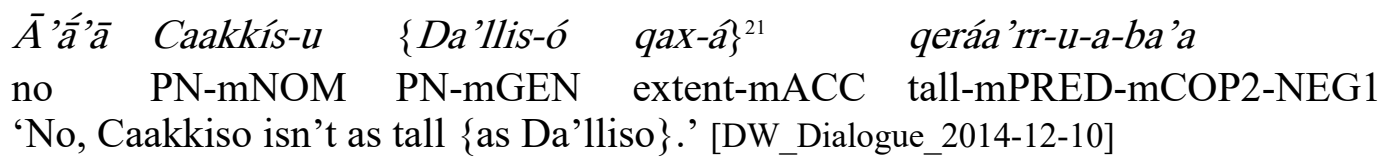

$\begin{array}{llll}\text { Siggis-í- } i & \text { isé } & \text { qax-á\} } & \text { bíishsh-a-ta } \\ \text { PN-fNOM-ADD } & \text { 3fGEN } & \text { extent-mACC } & \text { red-fPRED-fCOP2 } \\ \text { 'Siggise, too, is as light-skinned (lit. red) } & \text { as she (is) }\} . \text {.' [Elicited] }\end{array}$

Even though equative examples with qax-á have been readily provided by Kambaata speakers in elicitation sessions, they are much less common than equative construction with $=g$ in spontaneously produced data; note, however, that (75) is a non-elicited example. It is not clear whether equality expressions with qax-á should be interpreted as a dedicated, conventionalised construction. In particular, it would be interesting to explore the semantic parameter type that qax$a$ can be used with, and the type of equative relation it can express.

In spite of elicited examples such as (76), in which the parameter of comparison is colour, qax$a$ seems to be used primarily for the expression of equality in size and equality of amount. Furthermore, if the parameter of comparison is not overtly expressed (77)-(78) and if qax-á thus functions as the predicate of the equative construction, the implicit parameter of comparison is always understood to be size or amount, which shows that qax-á is not (yet?) a semantically void standard marker. ${ }^{22}$
$\mathrm{Ku}$
bóos-u
hikkánni-a
qáx-a

A_DEM1.mNOM water_pot-mNOM P_DEM2.mGEN-mCOP2 extent-mPRED

'This water-pot is as (implicit parameter: big) as that one.' [Elicited]

$\begin{array}{llll}\text { Kan } & \text { boos-í } & \text { wó'-u } & \text { qakkíchch-u-a } \\ \text { A_DEM1.mOBL } & \text { water_pot-mGEN } & \text { water-mNOM } & \text { tiny-mPRED-mCOP2 }\end{array}$

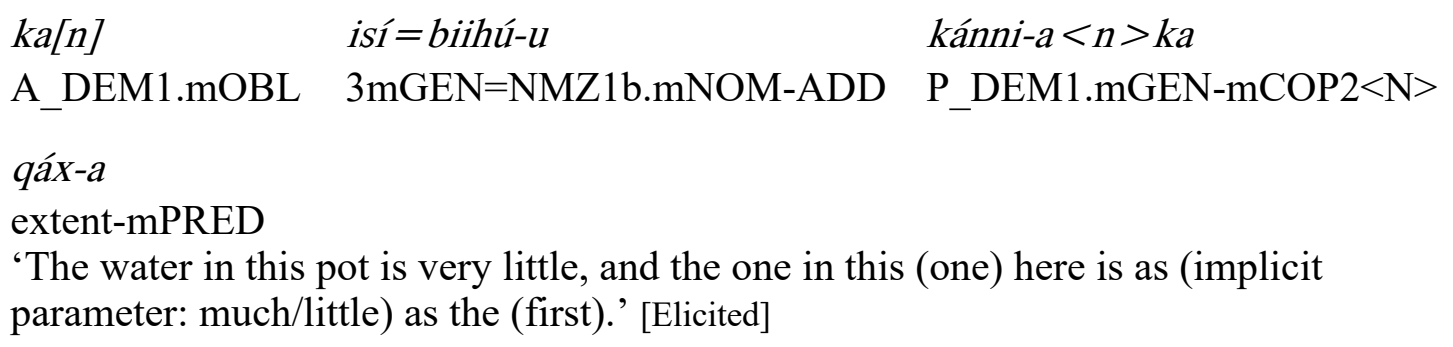

\footnotetext{
${ }^{21}$ A native speaker noted that Da'llis-ó qax-á could here be replaced by $D a{ }^{\prime} l l i s o ́=g-a(\S 5.1)$ without any apparent change in meaning.

${ }^{22}$ Note that size/amount polysemy is also observed in the adjectives qah-ú(-ta) 'small (size); little (amount)' and $a b b$ á(-ta) 'big; much'.
} 
It is safe to say that the standard marker qax-á 'extent' is hardly grammaticalised. Unlike the manner nominaliser $=g$ used in the first type of equative construction, it is not phonologically eroded and shows no signs of being encliticised to the standard. As we will see next, it still qualifies as a full noun.

\subsubsection{The morphology and polysemy of qax-á}

Qax-á 'extent' is a masculine noun with full case-marking potential (Table 4). As such, it can be used in any syntactic function in the clause.

\begin{tabular}{|l|l|}
\hline ACC & $q a x$-á \\
\hline NOM & qáx-u \\
\hline GEN & $q a x-1 ́$ \\
\hline DAT & $q a x$-íi(-ha) qax-ée(-ha) \\
\hline ABL & qax-íichch qax-éechch \\
\hline ICP & qax-íin \\
\hline LOC & qax-áan \\
\hline OBL & qáx-a \\
\hline PRED & qáx-a \\
\hline
\end{tabular}

Table 4. Case paradigm of $q a x-a ́(\mathrm{~m}$.$) 'extent'$

The noun qax-á is highly polysemous and is used with the concrete lexical meanings 'amount, quantity, number' (79), ${ }^{23}$ 'volume, contents', 'size, height, length, circumference', '(spatial) distance, limit', and, as seen in (80), '(temporal) distance, period of time, while'.

Kánn qax-íichch m-á aass-áan-ke-la?

A_DEM1.mOBL amount-mABL what-mACC give-1sIPV-2sO-MIT

'What can I give you from this amount? (i.e. It is too small to share.)' [Elicited]

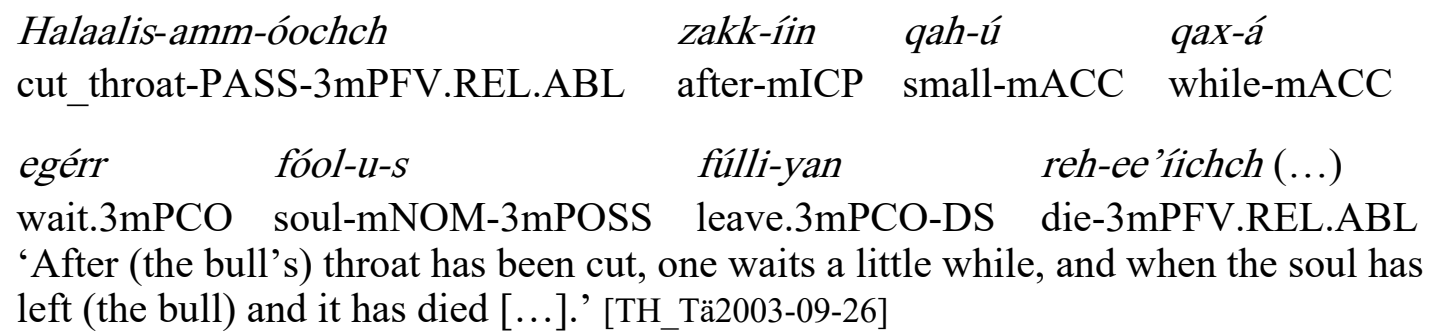

The noun qax-á is also used with a more abstract meaning 'degree' in (81).

\footnotetext{
${ }^{23}$ For a discussion of the use of qax-á to express approximate number see Treis (2017a: $\left.\S 9\right)$.
} 


\begin{tabular}{|c|c|c|c|}
\hline $\begin{array}{l}\text { Gaaz-í } \\
\text { fuel-mGEN }\end{array}$ & $\begin{array}{ll}\text { hír-at } & \text { ammóo } \\
\text { price-fNOM but }\end{array}$ & $\begin{array}{lll}o & \text { abbís-s } & \text { bar } \\
& \text { exceed-3fPCO } & \text { add }\end{array}$ & -itán \\
\hline \multicolumn{2}{|c|}{$\begin{array}{l}\text { gal-táyyoo }=\text { bikkíiha } \\
\text { spend_time-3fPROG.REL=REAS }\end{array}$} & $\begin{array}{l}z a b b-i-S i ́ \\
\text { medicine-mGEN-DEF }\end{array}$ & $\begin{array}{l}\text { hir-atí- } i \\
\text { price-fNOM-ADD }\end{array}$ \\
\hline DEM2.n & $\begin{array}{ll} & q a x-\hat{a}<n>k a \\
\mathrm{~N} & \text { degree-mACC }<\mathrm{N}\end{array}$ & $\begin{array}{l}\text { le’-áyyoo'u } \\
\text { grow-3fPROG }\end{array}$ & \\
\hline
\end{tabular}

'Because the price of fuel is rising, the price of medicine is rising at the (same) rate as that one (= the fuel).' (K89: 7.155)

The noun qax-á can also be an adverbial modifier of quality verbs, e.g. cúlu ass- 'be appealing (to somebody)' in (82).
Téesu hegeeg-ú-nne
xuud-deentí-raan
now
neighbourhood-mACC-1pPOSS
see-2sPRF-IRR
muccúrr
m-íi qax-á-ndo
cúlu
ass-áyyoo'u
be_clean.3mPCO what-mGEN degree-mACC-Q appealing make-3mPROG 'If only you could see to what degree/extent our neighbourhood has become clean and has been made appealing!' (K89: 4.126)

In accordance with universal processes of semantic change, it seems reasonable to assume that qax-á originally had a fairly concrete meaning of 'amount', 'size', 'distance', 'period of time' and only later developed the more abstract sense of 'degree', which facilitates its use in the expression of equality.

\subsubsection{The equative nomino-adjective $q a x-a ́(-t a)$}

Based on the stem of the noun qax-á illustrated in §5.2.1, Kambaata also has a dedicated equative nomino-adjective qax-á(-ta) 'which is/are (about) as much/many as, which has (about) the amount/size/ distance, etc. of' ${ }^{24}$ As a modifier, it agrees in case and gender with its head noun. In (83) the oblique case of qáx-ata signals agreement with a feminine non-nominative/non-accusative noun, more precisely with ma'nnéen fLOC 'at a place'. Furthermore, it agrees in gender with its

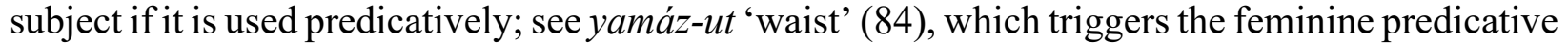
form of $q a x-a ́(-t a)$. The nomino-adjective qax-á(-ta) is often interpreted as expressing only approximate equality.

${ }^{24} \mathrm{Cf}$. dedicated quantitative equatives in European languages, as discussed in Haspelmath \& Buchholz (1998: 298$301)$. 
(83)

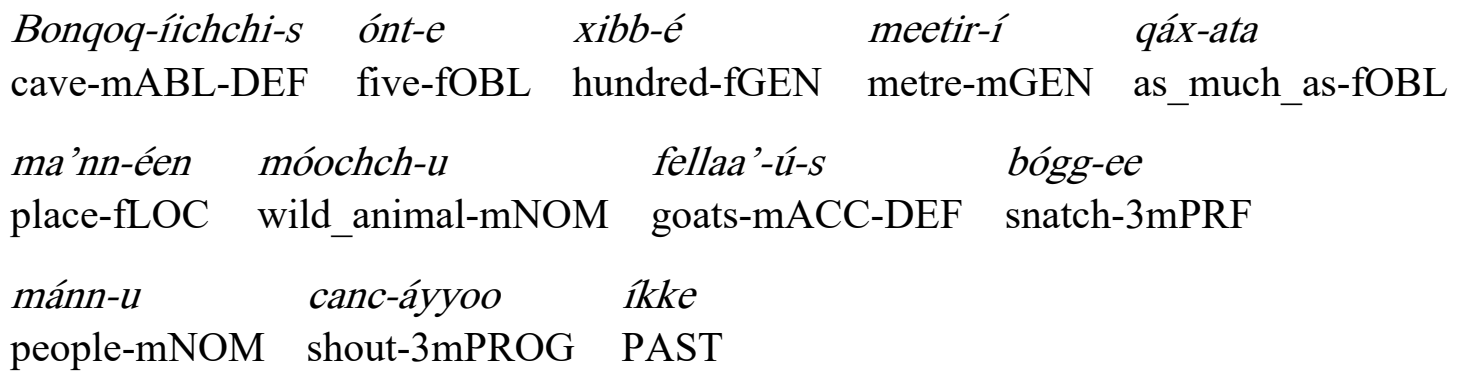

"At a place as much as/about 500 metres away from the cave, people whose goats had been snatched by a wild animal were shouting.' (K89: 8.22)

\section{Uull-á yamáz-ut 40 kum-é kilomeetír-i-ta \\ earth-fGEN waist-fNOM 40 thousand-fGEN kilometre-mGEN-fCOP2}

qáx-a

as_much_as-fPRED

'The circumference (lit. waist) of the earth is as much as/about $40,000 \mathrm{~km}$.' (K89: 6.164)

Unlike other adjectives in Kambaata, which can govern accusative, dative and ablative complements (Treis 2008: 90), qax-á(-ta) combines, unexpectedly, with a genitive phrase, as illustrated by meetir- $i$ 'of metre(s)' in (83). Other than that, only nouns (or enclitics of (pro)nominal origin) are modified by genitive phrases. Therefore, the word class status of qax-á(ta) cannot be determined unequivocally and it is called a nomino-adjective.

\subsubsection{Equative clauses with qax-á 'extent'}

If a clause headed by a finite verb expresses the standard of comparison in an equative construction, it is relativised and the clause is thus made the modifier of qax-á 'extent'. The standard marker occurs either in the accusative (85) or in the ICP case (86).

$$
\begin{aligned}
& \text { (...) }\{\text { iitt-itoonte-'é } q a x \text {-á }<n>k a\} \quad \text { isso'ootá-a } \\
& \text { love-2sPFV-1sO.REL extent-mACC }<\mathrm{N}>\quad 3 \text { AACC-ADD } \\
& \text { iitt-itoonti }=\text { g-á-a dag-gáa, } \\
& \text { love-2sPFV.REL=G-mACC/OBL-ADD know-3fIPV }
\end{aligned}
$$

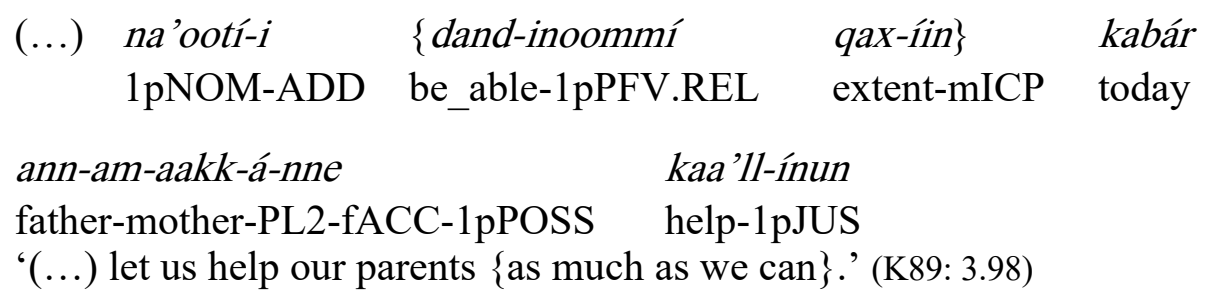


My corpus contains only quantitative equatives of the type ' $\mathrm{V}$ as much as' with a clausal standard where the parameter of comparison is implied in the standard marker qax-á 'extent'. Equatives with a clausal standard and an explicit non-quantitative parameter, e.g. "She is as intelligent/beautiful/nasty as we had assumed', are not attested. Neither do equative constructions with a clausal standard marked by $=g$ 'manner' (\$6.1) occur. Note, however, that $=g$ cannot replace $q a x-a ́$ in the examples in this section.

\section{Summary and cross-Cushitic comparison}

The Kambaata constructions used for the expression of the four types of comparison studied in this paper, i.e. comparison of relative superiority, absolute superiority (superlativity), equality and similarity, have been shown to have standard markers that are grammaticalised to different degrees. In the comparative construction, the standard phrase is marked by a true case morpheme, the ablative case, which is one of the nine cases for which nouns in Kambaata inflect. The same case morpheme is also used to mark the standard in one type of superlative construction, which is based on the comparative construction and in which the universal quantifier 'all' is the standard (' $\mathrm{X}$ is big from all'). In the second type of superlative construction, the standard of comparison is marked by the locative case (' $\mathrm{X}$ is big among $\mathrm{Y}$ ').

Like Kambaata, many East Cushitic languages mark the standard of comparison in comparative constructions by an ablative case morpheme or an ablative adposition; see K'abeena (Crass 2005: 296), Alaaba (Schneider-Blum 2007: 94f), Hadiyya (Sim 1989: 354), Afar (Hassan Kamil 2015: 363), Dullay (Amborn et al. 1980: 93, 101), Ts'amakko (Savà 2005: 127), and Somali (Saeed 1993: 107, 191f). The ablative is also one possible - but not the most common - standard marker in Sidaama (Kawachi 2011: 97). Furthermore, standards are ablative-marked in the Central Cushitic language Xamtanga (Darmon 2015: 324). In the East Cushitic group we also find languages that make use of locative adpositions as standard markers; see Konso (Ongaye 2013: 201, 179), Dhaasanac (Tosco 2001: 293) and Oromo (Owens 1985: 28, 77, 128, 233, 265 and elsewhere on Harar Oromo; Gragg 1982: 226 on Wellegga Oromo; Stroomer 1987: 50, 333 on Boraana Oromo). These languages contest Zelealem \& Heine's (2003: 60) claim that "the Source Schema provides the only or one of the main options for encoding comparatives [in the Ethiopian area]". The South Cushitic language Iraqw has a dedicated comparative morpheme (Mous 1993: $214,227)$. In Beja, the only North Cushitic language, the origin of the standard marker, which is also used as a parameter marker, is opaque. It may, however, be related to ablative morphemes in related languages (Vanhove 2017).

In the Cushitic literature, information on superlative constructions is sparse. The K'abeena and Alaaba grammars mention the use of comparative constructions with a universal quantifier (lit. ' $\mathrm{X}$ is big from all') for the expression of superlativity (Crass 2005: 297, Schneider-Blum 2007: 95). By way of contrast, in some Cushitic languages, we also find constructions without a universal quantifier and with unexpected structural differences between comparative and superlative constructions. While the Somali comparative construction marks the standard with an ablative preposition $k a ́$, the superlative standard is marked by an unrelated prepositional cluster $u$ gú, which might have originated from a combination of a dative 'to, for' and a locative preposition 'in(to), on, at, with' or a reduplicated dative preposition (Saeed 1993: 192, 201, 206). The illustrative sentences in Gragg's Oromo dictionary (1982) contain two kinds of superlatives. Some are based on the regular comparative construction with irra 'on' and with a universal quantifier as standard. Others use the locative postposition keessa 'in(side), into' > keessa-a (in-ABL) 'from among' (87). 

Bineensa
keessaa arbi
guddaa-d'a
[wild.animal
in. ABL
elephant
big-PRED]
'The elephant is the largest animal (lit. The elephant is big from among wild animals.).'
(Gragg 1982: 48; glossing and literal translation mine)

Finally, the Iraqw grammar contains a superlative example (Mous 1993: 214) with a locative preposition bará as a standard marker and a universal quantifier as part of the standard phrase. This construction is not based on the regular comparative construction with the dedicated standard marker $t a$.

In the Kambaata similative construction, the standard marker is not a case morpheme but a monosyllabic phrasal enclitic $=g$ of nominal origin. The morpheme can no longer be used without a host and has probably undergone phonological reduction in recent times (Kambaata does not have any monosyllabic nouns); it has, however, retained most features of a noun. The similative standard marker $=g$ is also the most common marker of the standard in equative constructions. Alternatively, Kambaata speakers make use of an equative periphrasis of the type ' $\mathrm{X}$ is tall to the extent of $Y$ '. The noun qax-á 'extent' does not seem to have undergone any phonological reduction and is still used as a full, albeit semantically polysemous (or vague) full noun.

Treis (2017b) shows that in Central Cushitic and Highland East Cushitic, the standard of comparison in similative constructions is marked by postposed morphemes, whereas in Lowland East Cushitic languages (with the exception of Afar and Saho) it is marked by preposed morphemes. Some Cushitic languages have two different similative morphemes that are used interchangeably in certain contexts (see also Kawachi forthcoming on Sidaama). The grammatical status of the standard marker varies from language to language. Whereas it is a (semi-)dependent morpheme in most Cushitic languages, in other languages it has a primary use as a free noun meaning 'manner'. And even if a language cannot (or can no longer) use its similative morpheme as a full noun, its presumed nominal origin may still be reflected in its case-marking potential or the formal marking of the standard that it governs (which is often marked for the genitive case). In 12 out of 20 Cushitic languages investigated by Treis (2017b) the similative standard marker is also employed as standard marker in equative constructions. Alternatively, some Cushitic languages use a noun 'extent' (or similar) as the head of the equative standard phrase; see Vanhove (2017) for Beja.

This paper has only been able to touch on some of the functions of the Kambaata enclitic morpheme $=g$ 'manner; like' in the section on similative and equative comparison. The morpheme is, however, highly multifunctional; a detailed description of this multifunctionality is provided in Treis (2017b). In the same publication some preliminary information can also found on the expression of hypothetical similarity ('do as if') (Treis 2017b: \$2.4). A more thorough investigation of this sub-type of comparison of similarity is still required.

\section{Abbreviations}

A_ adjective

AAM proprietive

ABL ablative

ADD additive ('also', 'and')

APPR apprehensive

CAUS causative

COND conditional 


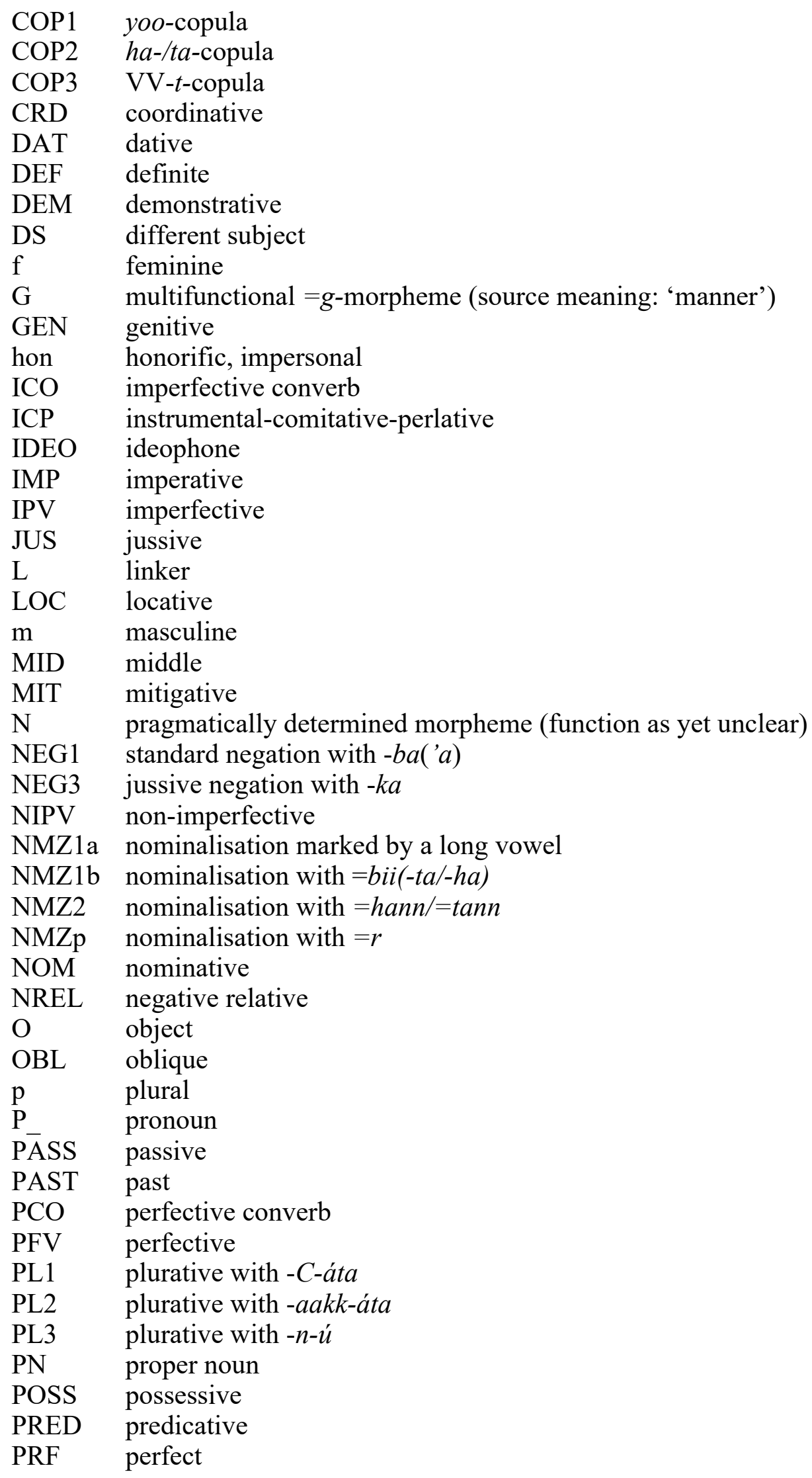




$\begin{array}{ll}\text { PROG } & \text { progressive } \\ \text { Q } & \text { question } \\ \text { REAS } & \text { reason } \\ \text { REL } & \text { relative } \\ \text { RHET } & \text { rhetorical question } \\ \text { S } & \text { singular } \\ \text { SG } & \text { singulative } \\ \text { VV } & \text { vowel lengthening }\end{array}$

\section{References}

Amborn, Hermann, Gunter Minker \& Hans-Jürgen Sasse 1980. Das Dullay. Materialien zu einer ostkuschitischen Sprachgruppe. Berlin: Reimer.

Crass, Joachim 2005. Das K'abeena. Deskriptive Grammatik einer hochlandostkuschitischen Sprache. (Kuschitische Sprachstudien, 23.) Cologne: Köppe.

Chelliah, Shobhana L. \& Willem J. de Reuse 2011. Handbook of Descriptive Linguistic Fieldwork. Dordrecht et al.: Springer.

Cuzzolin, Pierluigi \& Christian Lehmann 2004. Comparison and gradation. In: Booij, Gert et al. (eds.), Morphologie. Ein internationales Handbuch zur Flexion und Wortbildung, vol. 2, pp. 1857-1882. Berlin, New York: W. de Gruyter.

Darmon, Chloé 2015. A Morphosyntactic Description of Xamtanga, an Agaw (Central Cushitic) Language of the Northern Ethiopian Highlands. PhD thesis. Lyon: Université Lumière Lyon 2.

Dixon, R. M. W. 2008. Comparative constructions: a cross-linguistic typology. Studies in Language 32, 4: 787-817.

Fuchs, Catherine 2014. La comparaison et son expression en français. Paris: Ophrys.

Gasparini, Armido 1983. Sidamo-English Dictionary. Bologna: EMI.

Geetaahun Heelleebo Baachchoore 2002 E.C. Kambaatissa Afgale Maxaafa [Collection of Kambaata Oral Literature]. Tungu: Kambaatina Xambaaro Zoonaan, Dooyyoganni Woradaan, Maare-Ammachcho Waato.

Gorshenin, Maksym 2012. The crosslinguistics of the superlative. In: Stroh, Cornelia (ed.). Neues aus der Bremer Linguistikwerkstatt: Aktuelle Themen und Projekte 31, pp. 55-160. Bochum: Brockmeyer.

Gragg, Gene B. (ed.) 1982. Oromo Dictionary. East Lansing, MI: African Studies Center, Michigan State University.

Haspelmath, Martin \& Oda Buchholz 1998. Equative and similative constructions in the languages of Europe. In: van der Auwera, Johan (ed.). Adverbial constructions in the languages of Europe, pp. 277-334. Berlin: Mouton de Gruyter.

Haspelmath, Martin \& the Leipzig Equative Constructions Team 2017. Equative constructions in world-wide perspective. In: Treis, Yvonne \& Martine Vanhove (eds.). Similative and Equative Constructions: A Cross-linguistic Perspective. Amsterdam, pp. 9-32. Philadelphia: Benjamins.

Hassan Kamil, Mohamed 2015. L'afar: Description grammaticale d'une langue couchitique (Djibouti, Erythrée et Éthiopie). PhD thesis. Paris: INALCO.

Heine, Bernd 1997. Cognitive Foundations of Grammar. New York, Oxford: Oxford University Press.

Henkelmann, Peter 2006. Constructions of equative comparison. Sprachtypologie und Universalienforschung 59, 4: 370-398. 
K89 = Kambaatissata. Rosaanchi Maxaafa. [Kambaata Language. School Book.] 1989 E.C. Grade 1-8. Southern Nations, Nationalities, and Peoples Regional State: Education Bureau.

Kambaata and Hadiyya Translation Project Hosaina 2005. Yohaannis - Latin Version of the Gospel of John in Kambaata Language. Addis Ababa: The Bible Society of Ethiopia.

Kawachi, Kazuhiro 2007. A Grammar of Sidaama (Sidamo), a Cushitic Language of Ethiopia. $\mathrm{PhD}$ thesis, University at Buffalo, the State University of New York.

Kawachi, Kazuhiro 2011. Can Ethiopian languages be considered languages in the African linguistic area? In: Hieda, Osamu, Christa König and Hirosi Nakagawa (eds.). Geographical Typology and Linguistic Areas - with Special Reference to Africa, pp. 91-107. Amsterdam, Philadelphia: Benjamins.

Kawachi, Kazuhiro forthcoming. Sidaama. In: Tsunoda, Tasaku (ed.). Mermaid Constructions. (Comparative Handbooks of Linguistics) Berlin: De Gruyter Mouton.

Mous, Maarten 1993. A Grammar of Iraqw. Hamburg: Buske.

Ongaye Oda Orkaydo 2013. A Grammar of Konso. Utrecht: LOT.

Owens, Jonathan 1985. A Grammar of Harar Oromo (Northeastern Ethiopia). Hamburg: Buske.

Saeed, John 1993. Somali Reference Grammar. Kensington: Dunwoody Press.

Saint-Exupéry, Antoine de. 2018. Qakkichchu Laaha [The Little Prince]. Translated by Deginet Wotango Doyiso \& Yvonne Treis. Neckarsteinach: Tintenfaß.

Savà, Graziano 2005. A grammar of Ts' amakko. (Kuschitische Sprachstudien, 22.) Cologne: Köppe.

Schneider-Blum, Gertrud 2007. A Grammar of Alaaba, a Highland East Cushitic Language of Ethiopia. (Kuschitische Sprachstudien, 25.) Cologne: Köppe.

Sim, Ronald J. 1989. Predicate Conjoining in Hadiyya: A Head-Driven PS Grammar. PhD thesis. Edinburgh: University of Edinburgh.

Stassen, Leon 1985. Comparison and Universal Grammar. Oxford: Basil Blackwell.

Stassen, Leon. 2013. Comparative Constructions. In: Dryer, Matthew S. \& Martin Haspelmath (eds.). The World Atlas of Language Structures Online. Leipzig: Max Planck Institute for Evolutionary Anthropology. Available online at http://wals.info/chapter/121, accessed on 2015-01-07.

Stroomer, Harry 1987. A Comparative Study of Three Southern Oromo dialects in Kenya: Phonology, Morphology and Vocabulary. Hamburg: Buske.

Tosco, Mauro 2001. The Dhaasanac Language. (Kuschitische Sprachstudien, 17.) Cologne: Köppe.

Treis, Yvonne 2008. A Grammar of Kambaata. Part 1: Phonology, Morphology, and Non-verbal Predication. (Kuschitische Sprachstudien, 26.) Cologne: Köppe.

Treis, Yvonne 2012. Categorial hybrids in Kambaata. Journal of African Languages and Linguistics 33, 2: 215-254.

Treis, Yvonne 2017a. "They are only two, like the teats of a donkey": Kambaata denumerals revisited. In: Kramer, Raija \& Roland Kießling (eds.). Mechthildian approaches to Afrikanistik: Advances in language based research on Africa. Festschrift in honor of Mechthild Reh, pp. 339-366. Cologne: Köppe.

Treis, Yvonne 2017b. Similative morphemes as purpose clause markers in Ethiopia and beyond. In: Treis, Yvonne \& Martine Vanhove (eds.). Similative and Equative Constructions: A Crosslinguistic Perspective, pp. 91-142. Amsterdam, Philadelphia: Benjamins.

Vanhove, Martin 2017. Similative, equative, and comparative constructions in Beja (NorthCushitic). In: Treis, Yvonne \& Martine Vanhove (eds.). Similative and Equative Constructions: A Cross-linguistic Perspective, pp. 189-211. Amsterdam, Philadelphia: Benjamins. 
Wedekind, Klaus 1990. Generating Narratives: Interrelations of Knowledge, Text Variants and Cushitic Focus Strategies. Berlin: Mouton de Gruyter.

Zelealem Leyew \& Bernd Heine 2003. Comparative constructions in Africa: An areal dimension. Annual Publication in African Linguistics 1: 49-68. 